\title{
Insights into the roles of surface oxygen species of manganese oxides for the ozone elimination at ambient temperature
}

\author{
Lei Zhang ${ }^{1}$, sheng wang ${ }^{2}$, lirong $\mathrm{Lv}^{3}$, Yang Ding ${ }^{3}$, dongxu Tian ${ }^{3}$, and Shudong Wang ${ }^{3}$ \\ ${ }^{1}$ Dalian Institute of Chemical Physics \\ ${ }^{2}$ Dalian Institute of chemical physics \\ ${ }^{3}$ Affiliation not available
}

May 7, 2020

\begin{abstract}
Manganese oxides with varied Mn valance states but identical morphology were synthesized. Their behaviors of ozone decomposition were investigated following the order of Mn3O4 $<\mathrm{Mn} 2 \mathrm{O} 3<\mathrm{MnO} 2<\mathrm{MnO} 2-\mathrm{H}-200$. It was deduced that the superior O3 decomposition capacity for MnO2-H-200 was strongly associated with abundant oxygen vacancies. Among Mn3O4, Mn2O3 and $\mathrm{MnO} 2$, the difference on $\mathrm{O} 3$ decomposition efficiency was dependent on divergent nature of oxygen vacancy. DFT calculation revealed that $\mathrm{Mn} 3 \mathrm{O} 4$ and $\mathrm{MnO} 2$ possessed lower formation energy of oxygen vacancy, while $\mathrm{MnO} 2$ had the minimum desorption energy of peroxide species $\left(\mathrm{O} 2^{*}\right)$, suggesting that the promotion of the $\mathrm{O} 3$ decomposition capability was attributed to the easier $\mathrm{O} 2 *$ desorption. The insights on the deactivation mechanism for $\mathrm{MnO} 2-\mathrm{H}-200$ further validated the assumptions. As the reaction proceeded, adsorbed oxygen species accumulated on the catalyst surface, and a portion of them were transformed to lattice oxygen.
\end{abstract}

\begin{abstract}
Manganese oxides with varied Mn valance states but identical morphology were synthesized via a facile thermal treatment of $\gamma-\mathrm{MnOOH}$. And their behaviors of ozone decomposition were investigated following the order of $\mathrm{Mn}_{3} \mathrm{O}_{4}<\mathrm{Mn}_{2} \mathrm{O}_{3}<\mathrm{MnO}_{2}<\mathrm{MnO}_{2}-\mathrm{H}-200$. In combination with XRD, SEM, BET, TEM, $\mathrm{H}_{2}-\mathrm{TPR}$, $\mathrm{O}_{2}$-TPD and XPS characterization, it was deduced that the superior $\mathrm{O}_{3}$ decomposition capacity for $\mathrm{MnO}_{2}$ $\mathrm{H}-200$ was strongly associated with abundant oxygen vacancies on its surface. Among $\mathrm{Mn}_{3} \mathrm{O}_{4}, \mathrm{Mn}_{2} \mathrm{O}_{3}$ and $\mathrm{MnO}_{2}$, the difference on $\mathrm{O}_{3}$ decomposition efficiency was dependent on divergent nature of oxygen vacancy. DFT calculation revealed that $\mathrm{Mn}_{3} \mathrm{O}_{4}$ and $\mathrm{MnO}_{2}$ possessed lower formation energy of oxygen vacancy, while $\mathrm{MnO}_{2}$ had the minimum desorption energy of peroxide species $\left(\mathrm{O}_{2}{ }^{*}\right)$. It was deduced that the promotion of the $\mathrm{O}_{3}$ decomposition capability was attributed to the easier $\mathrm{O}_{2}{ }^{*}$ desorption. The insights on the deactivation mechanism for $\mathrm{MnO}_{2}-\mathrm{H}-200$ further validated the assumptions. As the reaction proceeded, adsorbed oxygen species accumulated on the catalyst surface, and a portion of them were transformed to lattice oxygen. An irreversible generation of oxygen vacancy led to the deactivation of the catalyst.
\end{abstract}

\section{Introduction}

Ozone $\left(\mathrm{O}_{3}\right)$ as a typical secondary pollution is considered to be detrimental to human health and plant growth because of its strong oxidation capacity $[1,2]$. It is generally recognized that the ground-level ozone is sourced from the photochemical reaction between volatile organic compounds (VOCs) and nitrogen oxides $\left(\mathrm{NO}_{\mathrm{x}}\right)$ in the presence of heat and sunlight. Since the concentration of VOCs and $\mathrm{NO}_{\mathrm{x}}$ has been increasing with the increasing of the population density of the world, ozone pollution becomes more and serious [3]. Especially in some special circumstance, ozone hazards are more prominent such as in indoor environment and aircraft cabin [4]. Thus, the U.S. Environmental Protection Agency updated the National Ambient Air 
Quality Standards for ground-level ozone from $75 \mathrm{ppb}$ to $70 \mathrm{ppb}$ [5]. Among the various routes known to eliminate ozone contamination, ozone catalytic decomposition has shown significant promise as an alternative way due to its efficiency and safety. Nevertheless there are a number of desirable characteristics for an ozone decomposition catalyst, among which superior activity and stability are crucial. Of course low cost is also a pursuit in view of application. Though precious metals own higher performance for ozone decomposition, transition metal oxides still are the optimum option in consideration of the scarcity of precious metals. Among transition metal oxides such as $\mathrm{Co}_{3} \mathrm{O}_{4}, \mathrm{CeO}_{2}, \mathrm{CuO}$ and $\mathrm{MnO}_{2}$ etc, $\mathrm{MnO}_{2}$ is the most active oxide owing to multiple valence states [6]. As a result, numerous manganese oxides $\left(\mathrm{MnO}_{\mathrm{x}}\right)$ with different $\mathrm{Mn}$ valences or particle morphologies have been reported with satisfactory catalytic performance for ozone elimination over the recent years $[7,8]$. However, $\mathrm{MnO}_{\mathrm{x}}$ is easily deactivated in the presence or absence of water vapor, so the reason why the catalyst deactivated is important for the rational design of the effective catalyst $[9,10]$.

Possible ozone decomposition mechanism over $\mathrm{MnO}_{\mathrm{x}}$ catalyst was investigated by detecting the intermediate species. The peroxide species were identified by in situ Raman spectroscopy with isotopic labeling experiments by Oyama et al, and the reaction mechanism was elucidated as below [11, 12]:

$\mathrm{O}_{3}+*_{-} \mathrm{O}^{*}+\mathrm{O}_{2}(1)$

$\mathrm{O}_{3}+\mathrm{O}^{*}-\mathrm{O}_{2} *+\mathrm{O}_{2}(2)$

$\mathrm{O}_{2} *-\mathrm{O}_{2}+*(3)$

in which ${ }^{*}$ represents the active sites, and $\mathrm{O}_{2}{ }^{*}$ stands for peroxide species. The primary reactions above are generally assumed to take place at oxygen vacancies with cations on the $\mathrm{MnO}_{\mathrm{x}}$ surface, since oxygen vacancies can influence the $\mathrm{O}_{3}$ and/or oxygen intermediates adsorption/desorption behaviors [10, 13-17]. Zhu et al showed that the adsorption energy of $\mathrm{O}_{3}$ was increased when oxygen vacancies were generated into the $\alpha-\mathrm{MnO}_{2}$ lattice, indicating oxygen vacancies were more favorable for $\mathrm{O}_{3}$ adsorption [15]. Gong et al [18] found that cubic $\mathrm{Cu}_{2} \mathrm{O}$ exposed plane owned higher efficiency of $\mathrm{O}_{3}$ decomposition and resistance to water vapor, which was ascribed to weakly adsorbed $\mathrm{O}_{2}{ }^{*}$ intermediate on the cubic $\mathrm{Cu}_{2} \mathrm{O}$. According to defect engineering, the adsorption strength of binding of adsorbed oxygen intermediates to the $\mathrm{MnO}_{\mathrm{x}}$ surface depends on the property of oxygen vacancies, which is related to the elemental composition and structure of $\mathrm{MnO}_{\mathrm{x}}[19,20]$. As the most efficient catalyst for $\mathrm{O}_{3}$ decomposition, $\mathrm{MnO}_{\mathrm{x}}$ was widely studied owing to its multiple oxidation states. Higher $\mathrm{Mn}^{3+}$ ratio on $\mathrm{Mn} / \mathrm{TiO}_{2}$ owned superior $\mathrm{O}_{3}$ decomposition activity [21]. Similar result was obtained that manganese with lower oxidation states was favorable in decomposition of ozone [22, 23]. As indicated that the valence of Mn can significantly influence the ozone decomposition performance. Moreover, when Mn was coated on the support, the introduction of support will add the complexity between Mn valence and activity [24, 25]\{Rakesh Radhakrishnan, 2001 \#725\}. Therefore, to avoid the effects of support, it is necessary that pure $\mathrm{MnO}_{\mathrm{x}}$ should be synthesized to elucidate the intrinsic mechanism on $\mathrm{O}_{3}$ decomposition. Even for the unsupported $\alpha-\mathrm{MnO}_{2}$, the $\alpha-\mathrm{MnO}_{2}$ nanofibers exhibited the best activity, which is ascribed to abundant oxygen vacancy on its preferentially exposed (211) facet [26]. So the effects of morphology should be further avoided.

In the study, $\mathrm{MnO}_{2}, \mathrm{Mn}_{2} \mathrm{O}_{3}$ and $\mathrm{Mn}_{3} \mathrm{O}_{4}$ nanorods with identical morphologies were synthesized and oxygen vacancies were introduced to the surface of $\mathrm{MnO}_{2}-\mathrm{H}-200$ via hydrogen reduction. Their behaviors of ozone decomposition were studied. The dependence of their catalytic activity on the surface Mn valence was investigated. In combination with DFT calculation, the intrinsic mechanisms were also analyzed on $\mathrm{O}_{3}$ catalytic decomposition.

\section{Experimental section}

\subsection{Catalyst preparation}

Firstly, $\gamma$-MnOOH nanorod was synthesized by a facile redox precipitation process. Then the corresponding $\beta-\mathrm{MnO}_{2}, \alpha-\mathrm{Mn}_{2} \mathrm{O}_{3}$ and $\mathrm{Mn}_{3} \mathrm{O}_{4}$ were prepared by calcining $\gamma-\mathrm{MnOOH}$ nanorods under different temperature and atmosphere. The details of preparation precedure and chemicals invloved are shown in Supporting information (SI). 


\subsection{Characterization}

The crystalline structure of as-prepared samples was characterized by XRD. And their morphologies were observed by SEM and TEM. Texture properties were obtained by $\mathrm{N}_{2}$-adsorption isotherms. And their redox capacities were tested by $\mathrm{H}_{2}$-TPR and $\mathrm{O}_{2} / \mathrm{O}_{3}$-TPD. To further validate the oxygen mobility on the samples, XPS, FT-IR and Raman spectroscopies were also measured. The details of characterization are shown in Supporting information (SI).

\subsection{Computational Methods}

Density functional theory (DFT) calculations were carried out by the Vienna ab initio simulation package (VASP). The projector augmented wave (PAW) pseudo-potential was adopted to describe the ion-electron interactions, and the PW91 gradient-corrected functional was employed in the calculation of the exchange correlation energy. An energy cutoff of $400 \mathrm{eV}$ was used for the plane-wave basis set. Numerical convergence thresholds of $10^{-6} \mathrm{eV}$ in energy and $10^{-2} \mathrm{eV} / \AA$ in force were achieved on structural optimization. The Brillouin zone was sampled on the basis of the Monkhorst-Pack scheme with a $5 \times 5 \times 1$ k-point mesh [27]. A five-layer slab was used in the calculations. The atoms in the top two layers were fully relaxed while the rest of the atoms were fixed in their equilibrium positions.

Formation energy $\left(E_{\mathrm{f}}\right)$ of oxygen vacancy is defined as shown in the formula (4):

$E_{\mathrm{f}}=E_{\mathrm{v}}-E_{\mathrm{i}}-1 / 2 E_{\mathrm{O} 2}(4)$

$E_{\mathrm{v}}$ and $E_{\mathrm{i}}$ are total energy of the structure with and without an oxygen vacancy. $E_{\mathrm{O} 2}$ is the total energy of an oxygen molecule.

The oxygen adsorption energy $E$ o was defined relative to the isolated substrate and the $\mathrm{O}_{2}$ in the gas phase, as shown in the formula (5):

$E_{\mathrm{O}}=E_{[\text {surf }+\mathrm{O}]}-E_{[\text {surf }]}-1 / 2 E_{\mathrm{O} 2}(5)$

where $E_{\text {[surf }+ \text { O] }}$ and $E_{\text {[surf] }}$ are the total energies of the surface with and without the $\mathrm{O}$ adsorbate, respectively. $E \mathrm{O}_{2}$ is the total energy of an oxygen molecule.

\subsection{Catalyst Activity Measurement}

The activity of as-prepared samples for ozone decomposition was measured in a fixed bed continuous flow quartz reactor $\left(6 \mathrm{~mm}\right.$ i.d) using $0.1 \mathrm{~g}$ of catalyst with size of $40-60$ mesh at a temperature of $30^{\circ} \mathrm{C}$. The total gas flowrate was $1000 \mathrm{~mL} / \mathrm{min}$ with $500 \mathrm{~mL} / \mathrm{min}$ air and $500 \mathrm{~mL} / \mathrm{min} \mathrm{Ar}$, then the weight space velocity was $600,000 \mathrm{~mL} \cdot \mathrm{h}^{-1} \cdot \mathrm{g}^{-1}$. Ozone was generated by the electrical stimulation of oxygen (OSAN, Dalian) and the inlet ozone concentration was $15 \mathrm{ppm}$. An ozone analyser (Model 49i, Thermo Scientific, USA) was used to detect the inlet and outlet ozone concentrations. The ozone conversion was calculated on the basis of inlet and outlet $\mathrm{O}_{3}$ concentration $(C)$ as follows:

$\mathrm{O}_{3}$ conversion $=(C$ in $-C$ out $) / C$ in $\times 100 \%(6)$

\section{Results and discussion}

\subsection{The crystal structures of the catalysts}

The structure of the products by calcining the $\gamma-\mathrm{MnOOH}$ precursors (Figure S1) under different conditions was studied by XRD measurement. For clarity, the diffraction peak positions and the relative intensities of the standard patterns of $\mathrm{MnO}_{2}, \mathrm{Mn}_{2} \mathrm{O}_{3}$, and $\mathrm{Mn}_{3} \mathrm{O}_{4}$ are also shown at the bottom of Figure 1. As can be seen from Figure 1, for the samples being calcined in air at $350^{\circ} \mathrm{C}$, all the peaks of XRD patterns could be indexed to tetragonal $\beta-\mathrm{MnO}_{2}$ (JCPDS card no. 72-1984). Further elevating temperature to $600^{\circ} \mathrm{C}$, cubic $\alpha-\mathrm{Mn}_{2} \mathrm{O}_{3}$ (JCPDS card no.71-0636) were obtained. Replacing the oxidative atmosphere to inert Ar, the obtained products consisted of tetragonal $\mathrm{Mn}_{3} \mathrm{O}_{4}$ (JCPDS card no. 80-0382). After hydrogen reduction, the XRD patterns denoted as $\mathrm{MnO}_{2}-\mathrm{H}-200$ were in good agreement with $\beta-\mathrm{MnO}_{2}$. However, the broad and 
weak XRD features of $\mathrm{MnO}_{2}-\mathrm{H}-200$ indicated that $\beta-\mathrm{MnO}_{2}$ owned a poor crystalline phase, which was led by introducing more defects during hydrogen reduction.

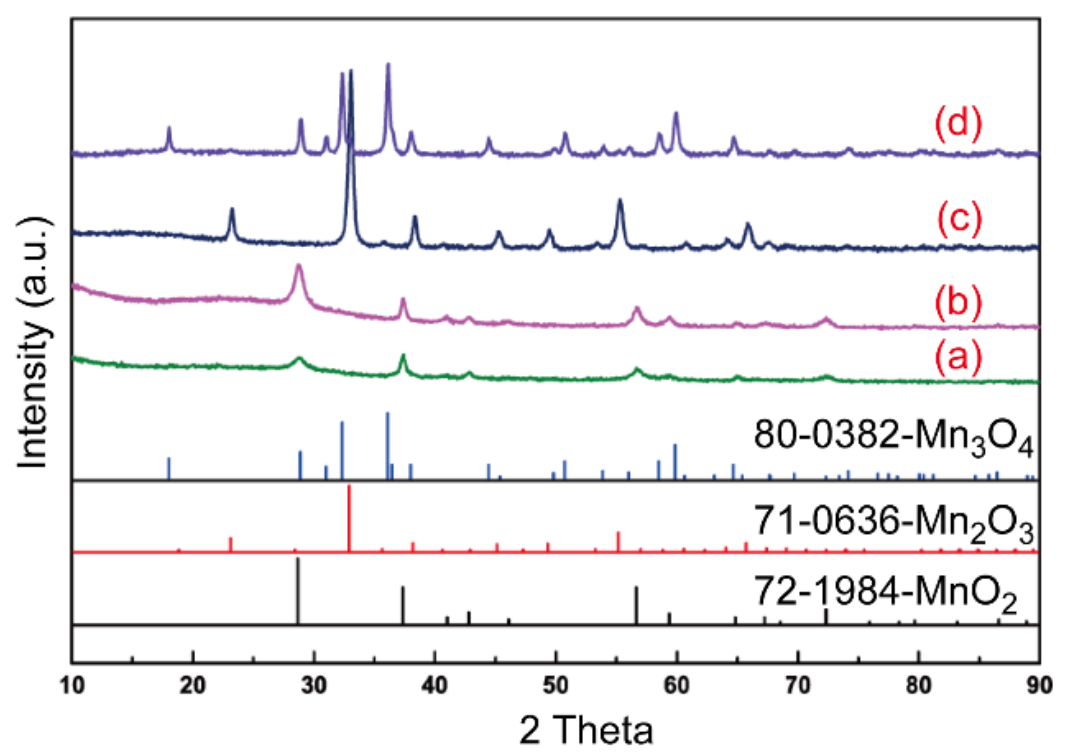

Figure 1. XRD patterns of the as-prepared products obtained by calcining the $\gamma-\mathrm{MnOOH}$ precursors under different conditions:(a) $350^{\circ} \mathrm{C}$ for $4 \mathrm{~h}$ in air and then $200^{\circ} \mathrm{C}$ for $2 \mathrm{~h}$ in $\mathrm{H}_{2}$ (b) $350^{\circ} \mathrm{C}$ for $4 \mathrm{~h}$ in air, (c) at $600^{\circ} \mathrm{C}$ for $2 \mathrm{~h}$ in air, (d) $600^{\circ} \mathrm{C}$ for $4 \mathrm{~h}$ in argon.

\subsection{The morphology and microstructures of the catalysts}

The morphologies of the as-obtained catalysts were investigated with SEM. Figure 2(a)-(d) showed the SEM images of $\mathrm{MnO}_{2}, \mathrm{Mn}_{2} \mathrm{O}_{3}, \mathrm{Mn}_{3} \mathrm{O}_{4}$ and $\mathrm{MnO}_{2}-\mathrm{H}-200$, respectively. For all samples, it could be seen that the shape was dominated by one dimensional nanorods with a diameter of tens of nanometers and a length of several micrometers. To study the detailed structural features, the micro-morphologies of four samples were characterized by TEM. Figure 3(b) showed that $\mathrm{MnO}_{2}$ possessed the inter-planar distance of $0.31 \mathrm{~nm}$, corresponding to the (110) plane of $\beta-\mathrm{MnO}_{2}$, which is in good agreement with the results of the selectedarea electron diffraction (SAED). The $\mathrm{MnO}_{2}$ had excellent crystallinity and displayed oriented growth along the [001] direction, and mainly exposed (110) facets. As shown in Figure 3(d) and (f), $\mathrm{Mn}_{2} \mathrm{O}_{3}$ and $\mathrm{Mn}_{3} \mathrm{O}_{4}$ preferentially exposed (211) and (200) facets, respectively. For $\mathrm{MnO}_{2}-\mathrm{H}-200$, the lattice fringe image became more indiscernible than $\mathrm{MnO}_{2}$ (Figure 3(h)). The indistinct lattice fringe image of $\mathrm{MnO}_{2}-\mathrm{H}-200$ suggested that defects were generated due to oxygen element escaping from the $\mathrm{MnO}_{2}$ lattice under $\mathrm{H}_{2} / \mathrm{Ar}$ atmosphere. 


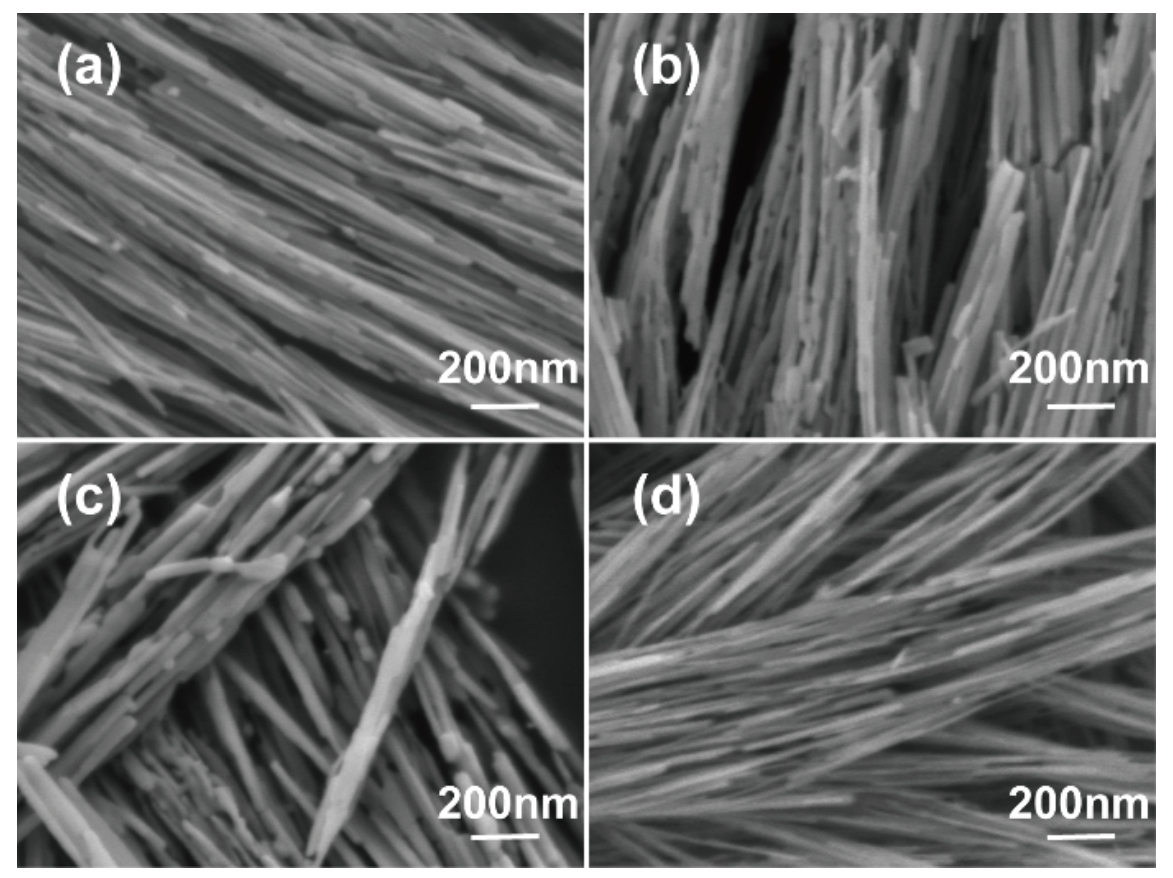

Figure 2. SEM images of $\mathrm{MnOx}$ catalysts: (a) $\mathrm{MnO}_{2}$, (b) $\mathrm{Mn}_{2} \mathrm{O}_{3}$, (c) $\mathrm{Mn}_{3} \mathrm{O}_{4}$, (d) $\mathrm{MnO}_{2}-\mathrm{H}-200$.

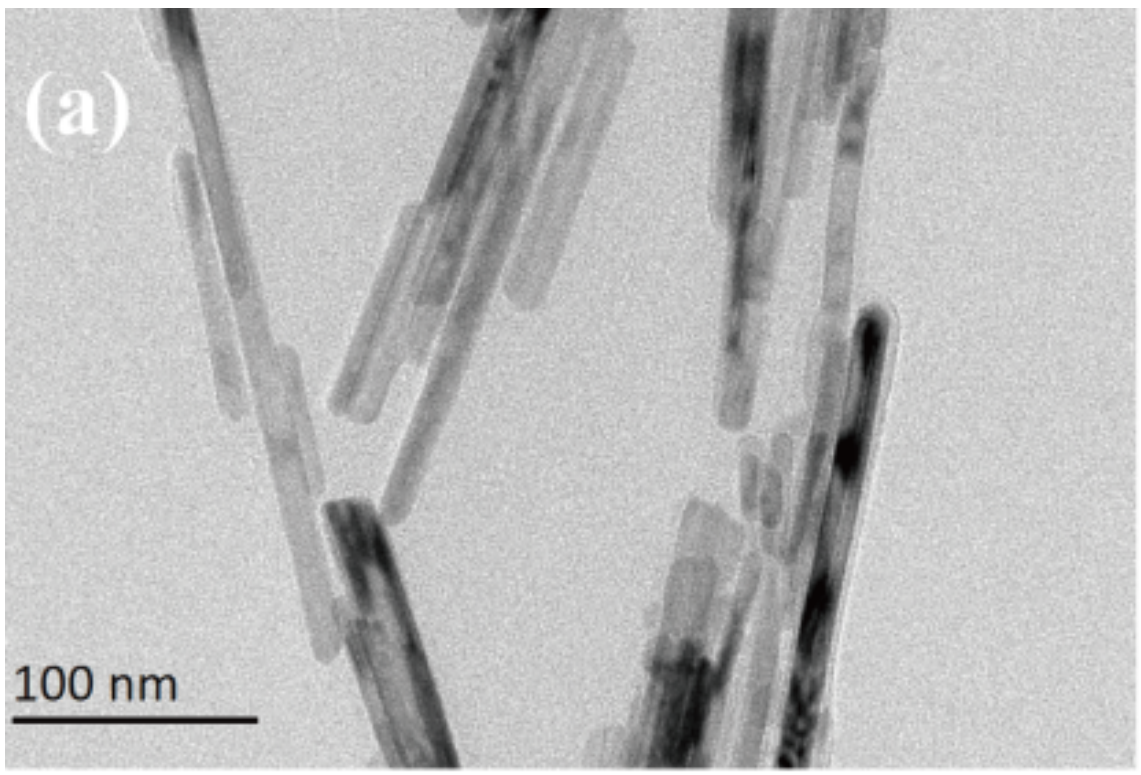



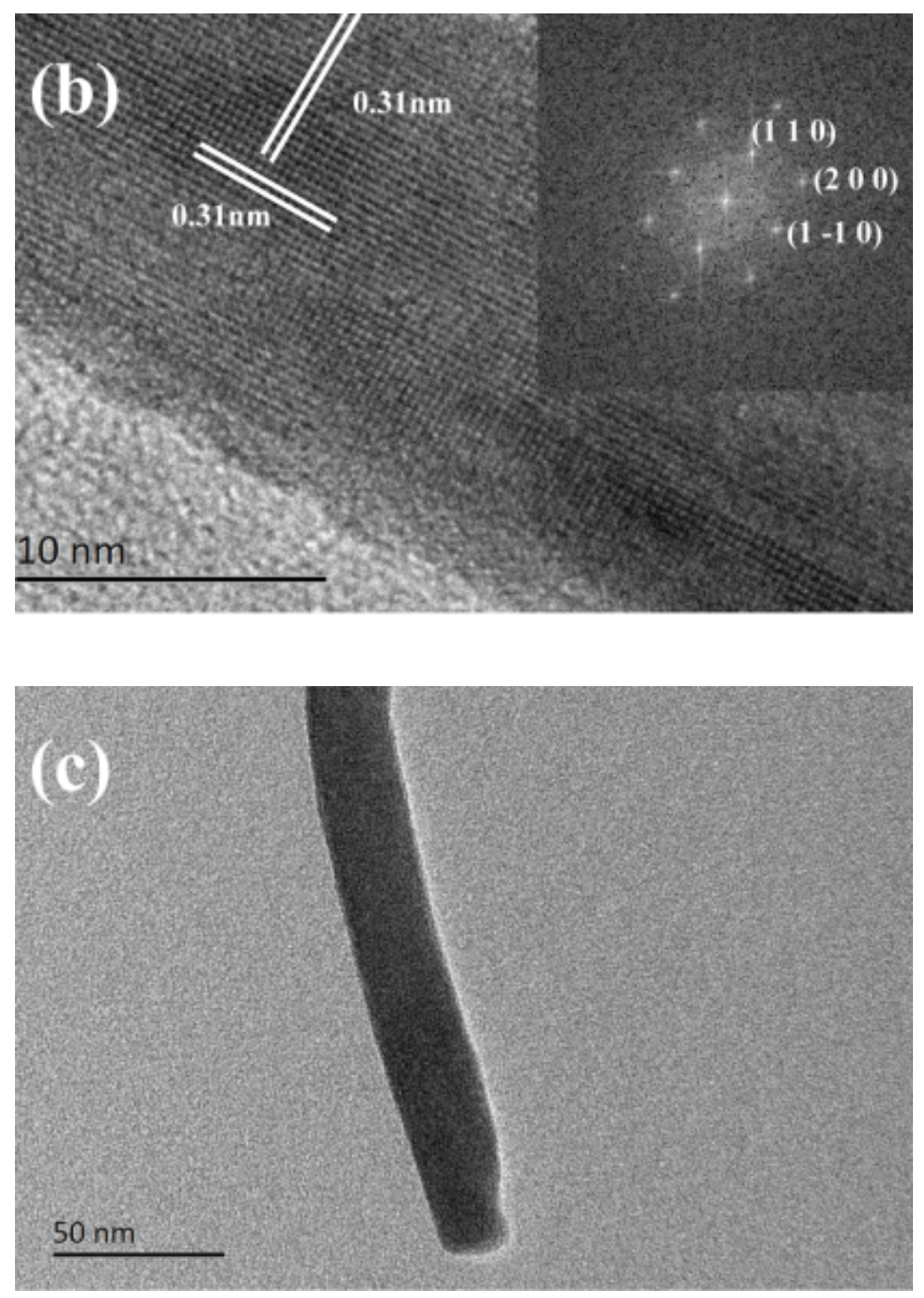


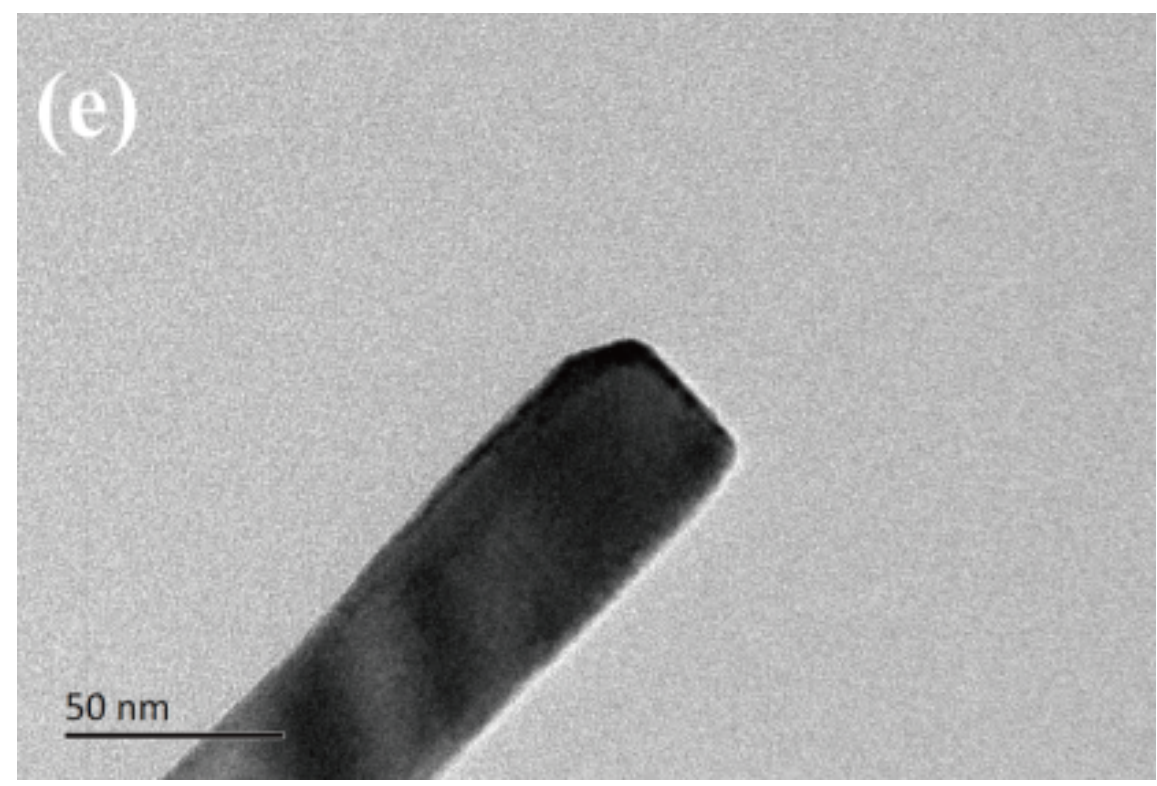

\section{(220)}

(0 - 20$)$

$10 \mathrm{~nm}$

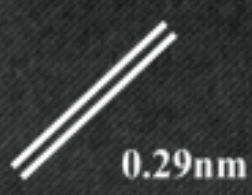



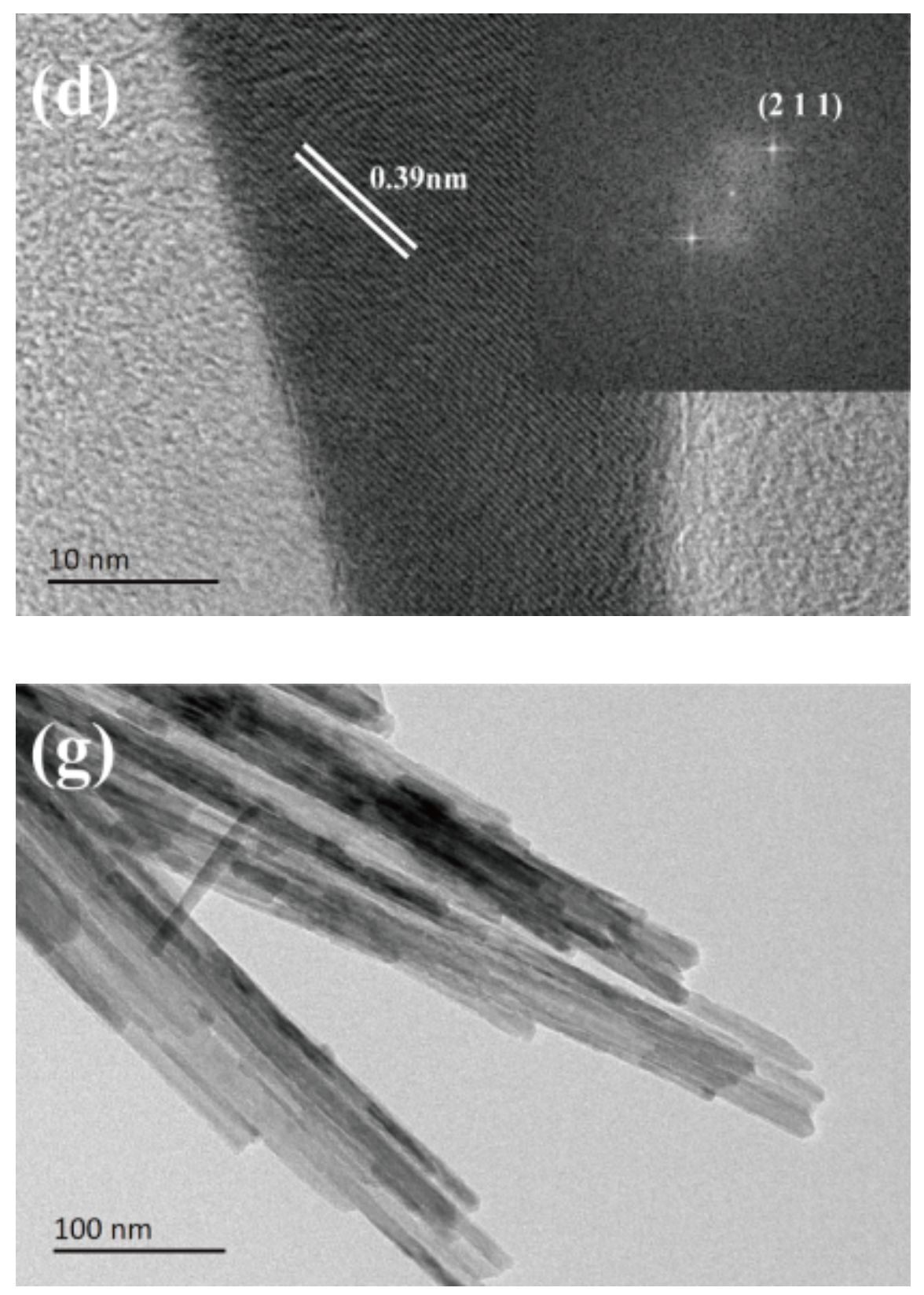


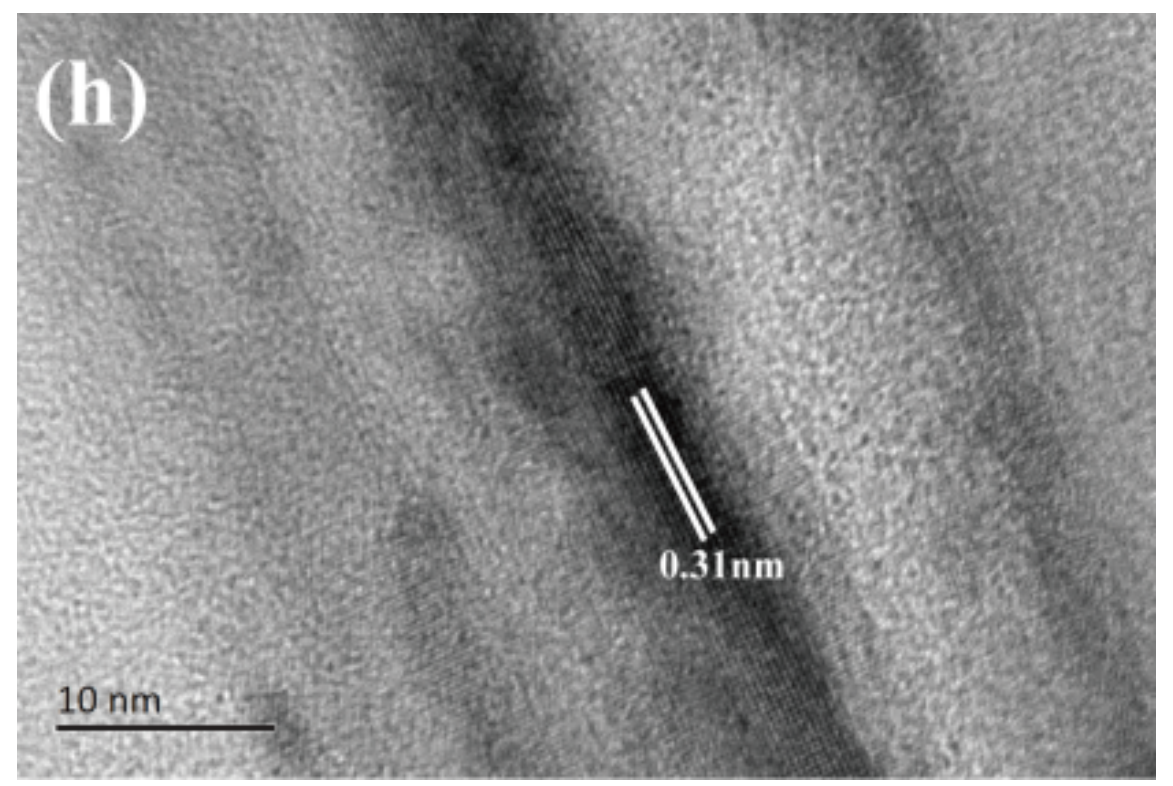

Figure 3. TEM images (with the SAED pattern inset) of $\mathrm{MnO}_{\mathrm{x}}$ catalysts: (a,b) $\mathrm{MnO}_{2}$, (c,d) $\mathrm{Mn}_{2} \mathrm{O}_{3}$, (e,f) $\mathrm{Mn}_{3} \mathrm{O}_{4}$, (g,h) $\mathrm{MnO}_{2}-\mathrm{H}-200$.

\subsection{The redox property of the catalysts}

The reducibility of the $\mathrm{MnO}_{\mathrm{x}}$ above has been evaluated by $\mathrm{H}_{2}$-TPR experiments and the results are shown in Figure 4. All the samples got green after $\mathrm{H}_{2}$-TPR experiments. It indicated the samples were reduced into $\mathrm{MnO}$. Only one reduction peak occurred for $\mathrm{Mn}_{3} \mathrm{O}_{4}$, which was attributed to the reduction of $\mathrm{Mn}_{3} \mathrm{O}_{4}$ to $\mathrm{MnO}$. While two peaks were detected over other samples. The lower-temperature peak was ascribed to the reduction of $\mathrm{MnO}_{2} / \mathrm{Mn}_{2} \mathrm{O}_{3}$ to $\mathrm{Mn}_{3} \mathrm{O}_{4}$, and the higher-temperature peak is attributed to the further reduction of $\mathrm{Mn}_{3} \mathrm{O}_{4}$ to $\mathrm{MnO}[28,29]$. Moreover, it should be noted that the low reduction temperature decreased from $306^{\circ} \mathrm{C}$ to $295^{\circ} \mathrm{C}$ for $\mathrm{MnO}_{2}$ and $\mathrm{MnO}_{2}-\mathrm{H}-200$. Generally, low onset reduction temperature corresponds to better reducibility. As shown in Figure 4, the reducibility lied in the following sequence: $\mathrm{Mn}_{3} \mathrm{O}_{4}<\mathrm{Mn}_{2} \mathrm{O}_{3}<\mathrm{MnO}_{2}<\mathrm{MnO}_{2}-\mathrm{H}-200$, implied that abundant oxygen vacancies or high $\mathrm{Mn}$ valence can enhance reducibility of $\mathrm{MnO}_{\mathrm{x}}$ catalyst. 


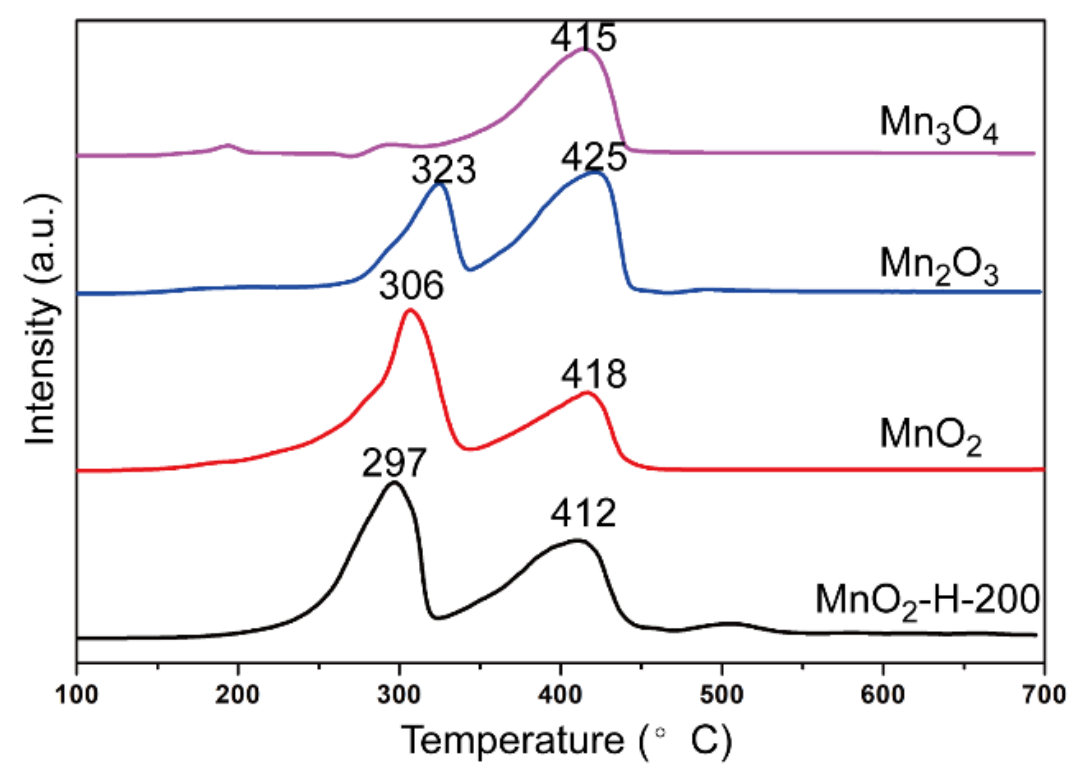

Figure 4. $\mathrm{H}_{2}$-TPR profiles of $\mathrm{MnO}_{\mathrm{x}}$ catalysts $\left(\mathrm{MnO}_{2}-\mathrm{H}-200, \mathrm{MnO}_{2}, \mathrm{Mn}_{2} \mathrm{O}_{3}\right.$ and $\mathrm{Mn}_{3} \mathrm{O}_{4}$

The type and mobility of oxygen species were determined by $\mathrm{O}_{2}$-TPD and the results were shown in Figure 5. Generally, the $\mathrm{O}_{2}$-TPD profile of $\mathrm{MnO}_{2}$ could be divided into three evolution peaks including low temperature $\left(<350^{\circ} \mathrm{C}\right)$, medium temperature $\left(350-600^{\circ} \mathrm{C}\right)$ and high temperature $\left(>600^{\circ} \mathrm{C}\right)[30]$. For the above $\mathrm{MnO}_{\mathrm{x}}$, the major peak centered at $519^{\circ} \mathrm{C}$ was ascribed to the transformation of $\mathrm{MnO}_{2}$ to $\mathrm{Mn}_{2} \mathrm{O}_{3}$ due to the release of lattice oxygen. The high temperature peak $\left(>800^{\circ} \mathrm{C}\right)$ was attributed to the successive transformation to $\mathrm{Mn}_{3} \mathrm{O}_{4}$. As shown in Figure 5, the oxygen desorption behaviors on manganese oxides at different valences were obviously different. Usually, the lower the desorption temperature of oxygen is, the looser it is bound to $\mathrm{Mn}$ within the $\mathrm{MnO}_{\mathrm{x}}$ lattice. Therefore, $\mathrm{MnO}_{2}$ and $\mathrm{MnO}_{2}-\mathrm{H}-200$ had higher oxygen mobility. The peak at below $200^{\circ} \mathrm{C}$ was sourced from the desorption of physically adsorbed $\mathrm{O}_{2}$ [31]. As shown in the inset of Figure 5 , the peak area of physically adsorbed $\mathrm{O}_{2}$ is remarkably larger than that of other samples, indicating that more active sites were provided on $\mathrm{MnO}_{2}-\mathrm{H}-200$. For $\mathrm{MnO}_{2}-\mathrm{H}-200$, a new peak at $270^{\circ} \mathrm{C}$ was assigned as the release of surface lattice oxygen and chemisorbed oxygen located at surface vacancies, indicating that hydrogen reduction enhance the mobility of oxygen species at low temperature, which was important for the ozone elimination activity. 


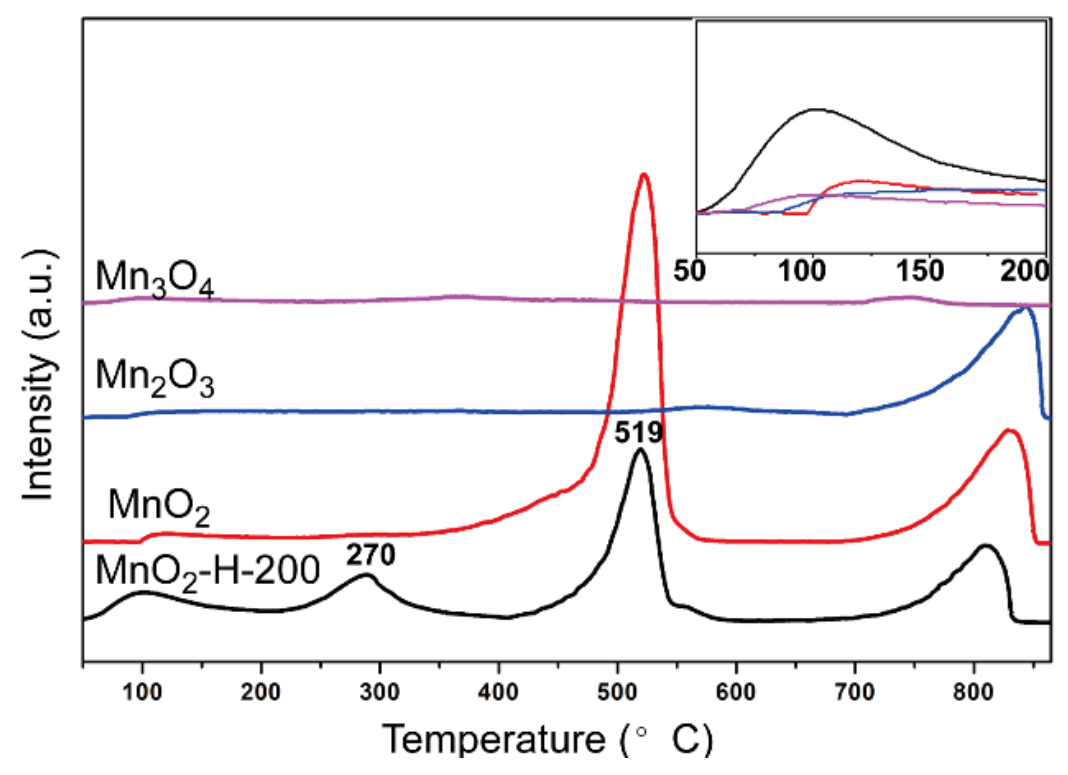

Figure 5. $\mathrm{O}_{2}$-TPD profiles of $\mathrm{MnO}_{\mathrm{x}}$ catalysts $\left(\mathrm{MnO}_{2}-\mathrm{H}-200, \mathrm{MnO}_{2}, \mathrm{Mn}_{2} \mathrm{O}_{3}\right.$ and $\left.\mathrm{Mn}_{3} \mathrm{O}_{4}\right)$, inset with the large view of the profiles at the temperature range of $50-200^{\circ} \mathrm{C}$

\subsection{The characteristics of oxygen vacancies}

The surface Mn state and oxygen species were investigated by XPS. The magnitude of Mn3s multiplet splitting could be used to calculate the average oxidation state(AOS) of Mn, according to the following relationship [32]:

$\mathrm{AOS}=8.956-1.126 \Delta E_{\mathrm{S}}(7)$

Where [?] $E_{\mathrm{s}}$ is the binding energy difference between the doublet Mn3s peaks shown in Figure 6a.The results were summarized in Table 1. The calculated AOSs of $\mathrm{MnO}_{2}, \mathrm{Mn}_{2} \mathrm{O}_{3}$ and $\mathrm{Mn}_{3} \mathrm{O}_{4}$ were lower than their theoretical values owing of surface oxygen defects. Moreover, the AOS of $\mathrm{MnO}_{2}-\mathrm{H}-200$ decreased to 3.22 from 3.78 of $\mathrm{MnO}_{2}$ suggesting that the density of oxygen vacancy was enhanced via hydrogen reduction.

For the above $\mathrm{MnO}_{\mathrm{x}}$, the O1s spectrum shown in Figure 6b could be deconvoluted into two peaks to gain information on the nature of oxygen species. The one with lower binding energy at 529.5-530.2eV was assigned as the lattice oxygen (denoted as $\mathrm{O}_{\text {latt }}$ ), and the other with higher binding energy at 531.3-531.4eV was ascribed as the surface-adsorbed oxygen (denoted as $\mathrm{O}_{\text {ads }}$ ). Generally oxygen molecules were adsorbed at the oxygen vacancies of an oxide material [33]. And the ratio of $\mathrm{O}_{\text {ads }} / \mathrm{O}_{\text {latt }}$ was an efficient parameter to characterize the relative abundance of oxygen vacancy in $\mathrm{MnO}_{\mathrm{x}}$. The more oxygen species adsorbed on the $\mathrm{MnO}_{\mathrm{x}}$ surface, the higher oxygen vacancy density was. As was shown in Table 1 , there were no remarkable differences on the ratios of $\mathrm{O}_{\text {ads }} / \mathrm{O}_{\text {latt }}$ for $\mathrm{MnO}_{2}, \mathrm{Mn}_{2} \mathrm{O}_{3}$ and $\mathrm{Mn}_{3} \mathrm{O}_{4}$. While $\mathrm{MnO}_{2}-\mathrm{H}-200$ exhibited the higher value of $\mathrm{O}_{\text {ads }} / \mathrm{O}_{\text {latt }}$ ratio than those of $\mathrm{MnO}_{2}, \mathrm{Mn}_{2} \mathrm{O}_{3}$ and $\mathrm{Mn}_{3} \mathrm{O}_{4}$, indicating that $\mathrm{MnO}_{2}-\mathrm{H}-200$ owned the most abundant surface adsorbed oxygen species, which was consistent with the results revealed by $\mathrm{O}_{2}-\mathrm{TPD}$. 

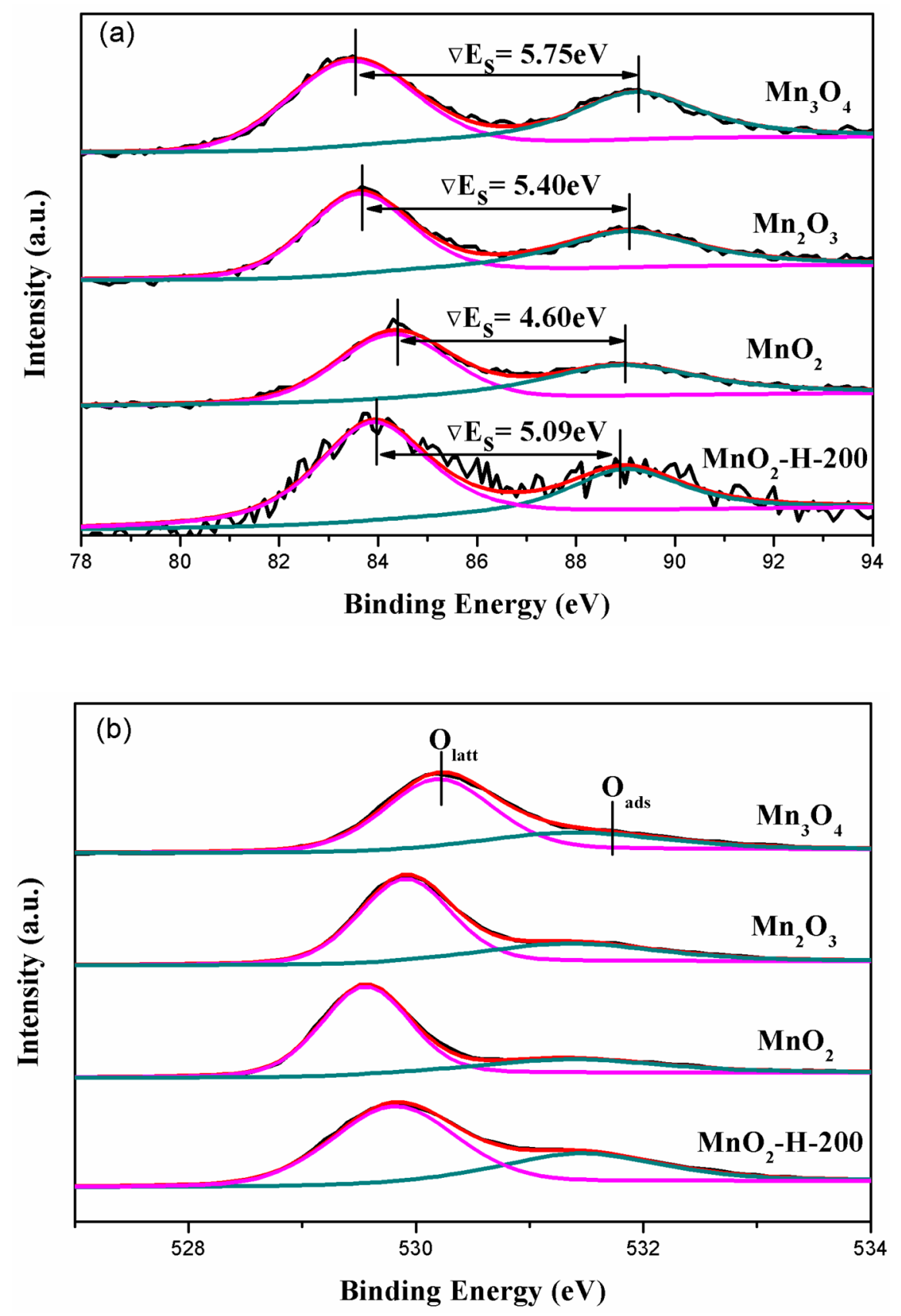

Figure 6 . (a) $\mathrm{Mn} 3 \mathrm{~s}$ and (b) O1s XPS spectra of $\mathrm{MnO}_{\mathrm{x}}$ catalysts $\left(\mathrm{MnO}_{2}-\mathrm{H}-200, \mathrm{MnO}_{2}, \mathrm{Mn}_{2} \mathrm{O}_{3}\right.$ and $\left.\mathrm{Mn}_{3} \mathrm{O}_{4}\right)$ Table 1. XPS results of $\mathrm{MnO}_{\mathrm{x}}$ catalysts $\left(\mathrm{MnO}_{2}-\mathrm{H}-200, \mathrm{MnO}_{2}, \mathrm{Mn}_{2} \mathrm{O}_{3}\right.$ and $\left.\mathrm{Mn}_{3} \mathrm{O}_{4}\right)$

\begin{tabular}{lllll}
\hline Catalysts & Mn3s AOS of Mn & $\begin{array}{l}\text { O1s binding energy } \\
(\mathrm{eV})\end{array}$ & $\begin{array}{l}\text { O1s binding energy } \\
(\mathrm{eV})\end{array}$ & $\begin{array}{l}\text { Relatively intensity } \\
\mathrm{O}_{\text {ads }} / \mathrm{O}_{\text {latt }}\end{array}$ \\
\hline & & $\mathrm{O}_{\text {latt }}$ & $\mathrm{O}_{\text {ads }}$ & \\
$\mathrm{Mn}_{3} \mathrm{O}_{4}$ & $2.48(8 / 3)$ & 530.2 & 531.3 & 0.26 \\
$\mathrm{Mn}_{2} \mathrm{O}_{3}$ & $2.88(3)$ & 529.9 & 531.3 & 0.29
\end{tabular}




\begin{tabular}{lllll}
\hline Catalysts & Mn3s AOS of $\mathrm{Mn}$ & $\begin{array}{l}\text { O1s binding energy } \\
(\mathrm{eV})\end{array}$ & $\begin{array}{l}\text { O1s binding energy } \\
(\mathrm{eV})\end{array}$ & $\begin{array}{l}\text { Relatively intensity } \\
\mathrm{O}_{\text {ads }} / \mathrm{O}_{\text {latt }}\end{array}$ \\
\hline $\mathrm{MnO}_{2}$ & $3.78(4)$ & 529.5 & 531.3 & 0.27 \\
$\mathrm{MnO}_{2}-\mathrm{H}-200$ & $3.22(4)$ & 529.8 & 531.4 & 0.55 \\
\hline
\end{tabular}

\subsection{Catalytic activities on ozone decomposition}

The catalytic activities of as-prepared $\mathrm{MnO}_{\mathrm{x}}$ catalysts for ozone decomposition were evaluated at $30^{\circ} \mathrm{C}$. As shown in Figure 7, the ozone conversion of all the $\mathrm{MnO}_{\mathrm{x}}$ decreased with reaction time. Nevertheless $\mathrm{MnO}_{2^{-}}$ $\mathrm{H}_{2}-200$ showed a better stability, and its ozone conversion kept above $96 \%$ after $12 \mathrm{~h}$ of reaction. While the conversion dropped to $87 \%$ for $\mathrm{MnO}_{2}, 43 \%$ for $\mathrm{Mn}_{2} \mathrm{O}_{3}$ and $12 \%$ for $\mathrm{Mn}_{3} \mathrm{O}_{4}$, respectively. $\mathrm{MnO}_{2}-\mathrm{H}_{2}-200$ showed the best performance of ozone decomposition due to the abundant surface oxygen vacancies revealed by $\mathrm{O}_{2}$-TPD and XPS analysis.

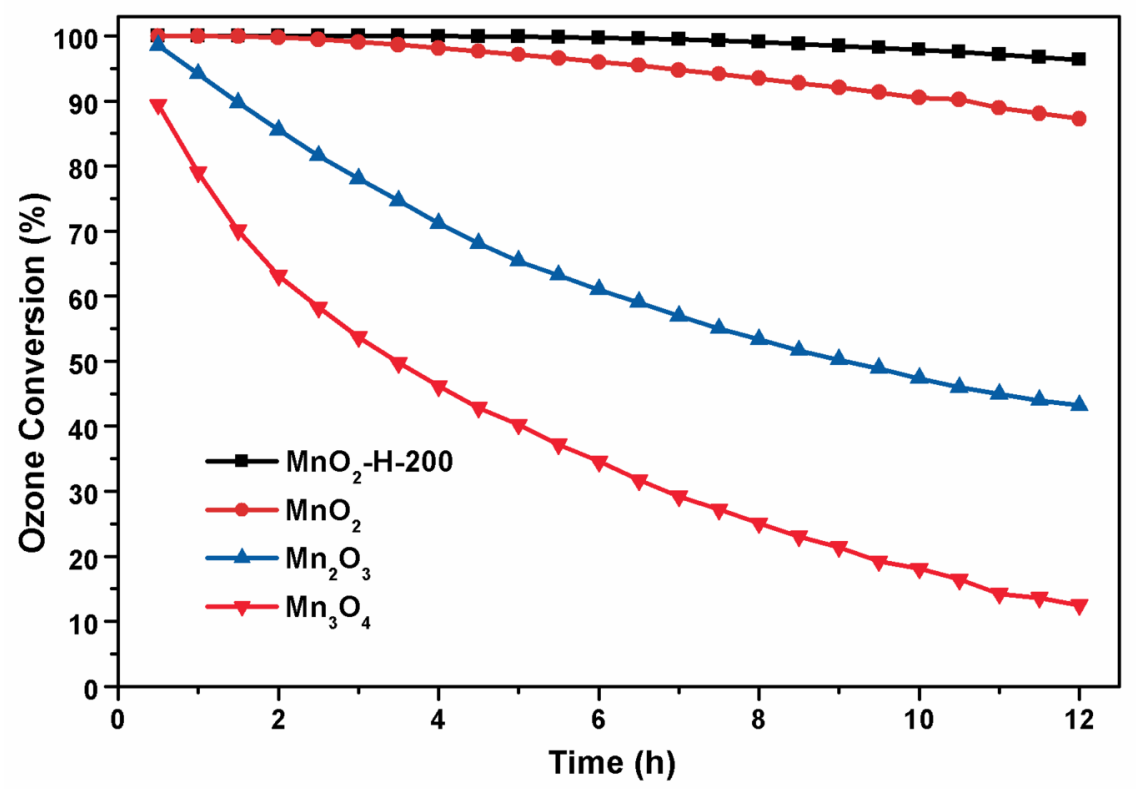

Figure 7 . Ozone conversion over different $\mathrm{MnO}_{\mathrm{x}}$ catalysts $\left(\mathrm{MnO}_{2}-\mathrm{H}-200, \mathrm{MnO}_{2}, \mathrm{Mn}_{2} \mathrm{O}_{3}\right.$ and $\left.\mathrm{Mn}_{3} \mathrm{O}_{4}\right)$

$\mathrm{MnO}_{2}, \mathrm{Mn}_{2} \mathrm{O}_{3}$ and $\mathrm{Mn}_{3} \mathrm{O}_{4}$ showed distinctly different performance on ozone decomposition, although they had almost the same $\mathrm{O}_{\text {ads }} / \mathrm{O}_{\text {latt }}$ ratio. As it is recognized that the improvement in catalytic performance may be due to higher surface area, BET surface area were obtained for the catalysts as shown in Table 2 and Figure S2. To exclude the influence from surface area, specific surface reaction rates of different $\mathrm{MnO}_{\mathrm{x}}$ were shown in Table 2, in the following order: $\mathrm{MnO}_{2}>\mathrm{Mn}_{2} \mathrm{O}_{3}>\mathrm{Mn}_{3} \mathrm{O}_{4}$. It indicated that their catalytic performances of $\mathrm{O}_{3}$ decomposition were not likely dependent on their surface area among $\mathrm{MnO}_{2}, \mathrm{Mn}_{2} \mathrm{O}_{3}$ and $\mathrm{Mn}_{3} \mathrm{O}_{4}$. The related study reported that the desorption of peroxide species $\mathrm{O}_{2}{ }^{*}$ was the rate-limiting step during ozone catalytic decomposition. And the desorption procedure is a reduction process, in which electrons were transferred to the manganese center by $\mathrm{O}_{2}{ }^{*}$ to form $\mathrm{O}_{2}$. That is to say, the easier $\mathrm{MnO}_{\mathrm{x}}$ reduces, the better the catalytic activity is. XPS results showed that the O1s binding energy of $\mathrm{O}_{\text {latt }}$ decreased in the following order: $\mathrm{MnO}_{2}(529.5 \mathrm{eV})<\mathrm{Mn}_{2} \mathrm{O}_{3}(529.9 \mathrm{eV})<\mathrm{Mn}_{3} \mathrm{O}_{4}(530.2 \mathrm{eV})$, suggesting that $\mathrm{MnO}_{2}$ had the most loosely bound of Mn-O or the highest mobility of oxygen, which was consistent with the results of $\mathrm{H}_{2}$-TPR and $\mathrm{O}_{2}$-TPD. Since the three catalysts had comparable $\mathrm{O}_{\text {ads }} / \mathrm{O}_{\text {latt }}$ ratio values, the nature of oxygen vacancies may play a crucial role in the desorption of $\mathrm{O}_{2}{ }^{*}$. However the gap on the nature of oxygen defects still needed to be elucidated by DFT calculation. 
Table 2. Reaction rate after $3 \mathrm{~h}$ time-on-stream test

\begin{tabular}{llll}
\hline Catalysts & $\begin{array}{l}\text { Specific surface area } \\
\mathrm{m}^{2} \mathrm{~g}^{-1}\end{array}$ & Reaction rate $\mu \mathrm{mol} \mathrm{g} \mathrm{g}^{-1} \mathrm{~h}^{1}$ & $\begin{array}{l}\text { Specific surface reaction } \\
\text { rate } \mu \mathrm{mol} \mathrm{m}^{-2} \mathrm{~h}^{-1}\end{array}$ \\
\hline $\mathrm{Mn}_{3} \mathrm{O}_{4}$ & 34.8 & 48.2 & 1.38 \\
$\mathrm{Mn}_{2} \mathrm{O}_{3}$ & 43.8 & 172.8 & 3.94 \\
$\mathrm{MnO}_{2}$ & 54.4 & 349.5 & 6.42 \\
$\mathrm{MnO}_{2}-\mathrm{H}-200$ & 66.0 & 385.7 & 5.84 \\
\hline
\end{tabular}

\subsection{DFT calculations}

The first-principle calculation was carried out using VASP program to further understand the formation of the oxygen vacancy and its effect on ozone decomposition. Based on the TEM images (Figure 3), the $\mathrm{MnO}_{\mathrm{x}}$ selectively exposed different favorable facets. On three types of facets, including $\mathrm{MnO}_{2}(110), \mathrm{Mn}_{3} \mathrm{O}_{4}$ (200) and $\mathrm{Mn}_{2} \mathrm{O}_{3}$ (211), the deoxidation kinetics were studied. Top, bridge and hollow oxygen vacancy sites were all examined for each facet (Figure S3-S5). Formation energy $\left(E_{\mathrm{f}}\right)$ of oxygen vacancy was theoretically studied to reveal the energy of removal of lattice oxygen, as shown in Table 3 . The process of oxygen vacancy formation often played a key role in catalytic activity, as for it was generally accepted as the active sites for ozone adsorption [34]. And literatures [9, 17] reported that the oxygen vacancy easier to be formed led to more active sites, resulting in a higher performance for ozone removal. In comparison with the oxygen vacancy formation energy, it can be drawn that the oxygen vacancy is difficult to form on $\mathrm{Mn}_{2} \mathrm{O}_{3}(211)$ surface, owing to the relatively higher formation energy. It could be explained by the different coordination number of oxygen to manganese atoms.

The process that the $\mathrm{O}_{2}{ }^{*}$ transforms into oxygen molecule can be viewed as oxygen desorption, so oxygen adsorption energy $\left(E_{\mathrm{o}}\right.$ ) on oxygen vacancy has been widely adopted as a descriptor for ozone elimination activity. The adsorption energy of $\mathrm{O}_{2}$ on different kinds of oxygen vacancies on $\mathrm{MnO}_{2}$ and $\mathrm{Mn}_{3} \mathrm{O}_{4}$ was also calculated and the results were shown in Table 3. Generally, a large $E_{\mathrm{o}}$ leads to the difficulty of the removal of $\mathrm{O}_{2}{ }^{*}$, thus catalytic activity was lowered. Compared to $\mathrm{Mn}_{3} \mathrm{O}_{4}(200), \mathrm{MnO}_{2}(110)$ was favorable for adsorbed $\mathrm{O}_{2}{ }^{*}$ to desorb from the oxygen vacancy sites. A three-step sequence mechanism was reasonable to describe ozone decomposition on manganese oxides, (i) dissociative adsorption of ozone to form an $\mathrm{O}_{2}$ molecule and an atomic $\mathrm{O}$, with low energy barrier of $6 \mathrm{~kJ} / \mathrm{mol}$, (ii) reaction of the atomic $\mathrm{O}$ with gaseous ozone to form a peroxide species and an $\mathrm{O}_{2}$ molecule, and (iii) desorption of $\mathrm{O}_{2}$ to restore oxygen vacancy. The step (iii) is proved to be the rate-limiting step. Comparing with the oxygen adsorption energy, $\mathrm{MnO}_{2}(110)$ was favorable for the regeneration of the oxygen vacancies, enhancing the $\mathrm{O}_{3}$ elimination capability, as shown in Figure 8. It is in good agreement with the experimental results.

Table 3. Formation energy $\left(E_{\mathrm{f}}\right)$ and oxygen adsorption energy $\left(E_{\mathrm{o}}\right)$ of different kinds of oxygen vacancies

\begin{tabular}{lllll}
\hline & & $\mathbf{M n O}_{\mathbf{2}}(\mathbf{1 1 0})$ & $\mathbf{M n}_{\mathbf{2}} \mathbf{O}_{\mathbf{3}} \mathbf{( 2 1 1 )}$ & $\mathbf{M n}_{\mathbf{3}} \mathbf{O}_{\mathbf{4}} \mathbf{( 2 0 0 )}$ \\
\hline Formation energy $\left(E_{\mathrm{f}}\right)(\mathrm{eV})$ & Top & $/$ & 6.1197 & $/$ \\
& Bridge & 2.9918 & 4.0208 & 2.0503 \\
\multirow{2}{*}{ Oxygen adsorption energy $\left(E_{\mathrm{o}}\right)(\mathrm{eV})$} & Hollow & 2.6895 & 5.1112 & $/$ \\
& Bridge & $-2,5564$ & $/$ & -4.3003 \\
& Hollow & -2.3758 & $/$ & $/$ \\
\hline
\end{tabular}




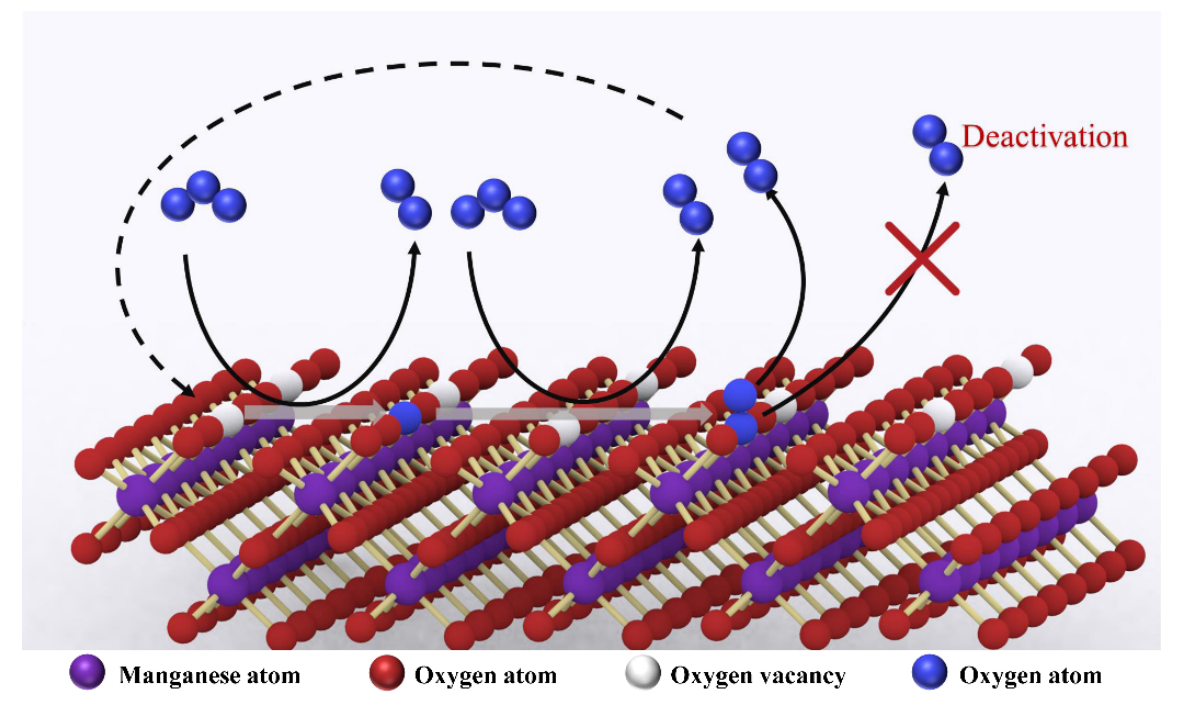

Figure 8 . Schematic illustration of $\mathrm{O}_{3}$ decomposition on $\mathrm{MnO}_{2}$.

\subsection{Mechanism of deactivation of ozone decomposition}

Since the catalytic performance decreased with the reaction time for all $\mathrm{MnO}_{\mathrm{x}}$, it is necessary to investigate the catalyst deactivation mechanism to develop more efficient catalyst. The physiochemical performances for $\mathrm{MnO}_{2}-\mathrm{H}-200$ before and after reaction were studied. The catalysts, its ozone conversion dropping to $60 \%$ and 20\%, were denoted as $\mathrm{MnO}_{2}-\mathrm{H}-200-0.6$ and $\mathrm{MnO}_{2}-\mathrm{H}-200-0.2$, respectively. The surface composition of the catalysts was investigated using XPS (Figure 9). The Mn AOS increased after reaction, accompanied with the binding energy of Mn2p shifting to higher energies, suggesting a higher Mn AOS for deactivated catalysts. And the peak intensity for surface adsorbed oxygen $\left(\mathrm{O}_{\text {ads }}\right)$ increased with the decline of ozone conversion, implying that the oxygen intermediates accumulated on the catalyst surface during the reactions. The intermediates occurring on the partially deactivated catalysts were characterized by FT-IR (Figure S6). The results indicated that a new peak at $1380 \mathrm{~cm}^{-1}$ occurred, which was assigned to oxygen species derived from peroxide species $\mathrm{O}_{2}{ }^{*}[35,36]$. Combined with XPS results, it was speculated that the irreversible $\mathrm{O}_{2}{ }^{*}$ desorption on oxygen vacancies led to the accumulation of intermediate oxygen species, resulting in the deactivation of $\mathrm{MnO}_{2}-\mathrm{H}-200$. 

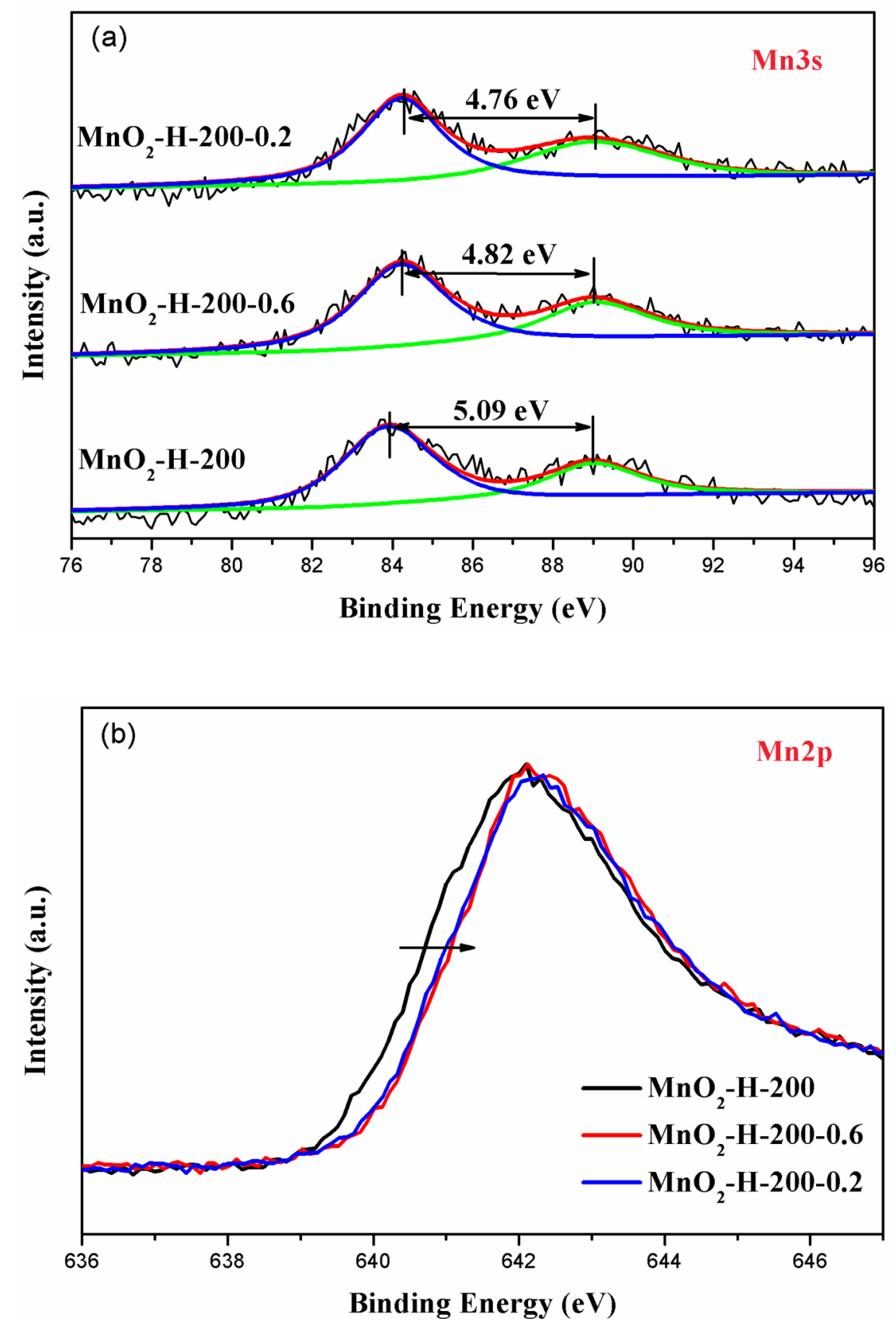


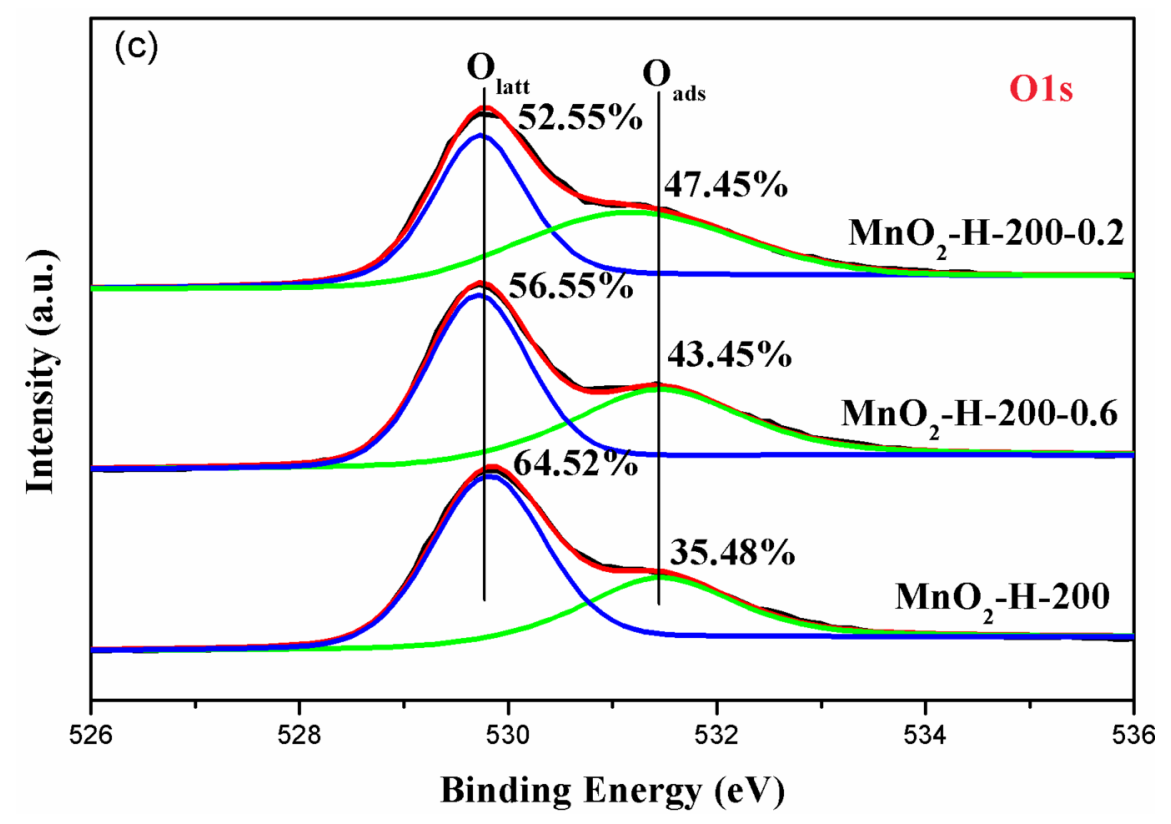

Figure 9 . (a) $\mathrm{Mn} \mathrm{3s}$, (b) $\mathrm{Mn} \mathrm{2} \mathrm{p}_{3 / 2}$ and (c) O1s XPS spectra of $\mathrm{MnO}_{2}-\mathrm{H}-200$ at different ozone conversion $(1,0.6$ and 0.2$)$

To further verify the irreversible $\mathrm{O}_{2}{ }^{*}$ desorption on $\mathrm{MnO}_{2}-\mathrm{H}-200, \mathrm{O}_{2}$-TPD was conducted and was shown in Figure 10. The $\mathrm{O}_{2}$-TPD profile in lower temperature range was deconvoluted into several peaks (Figure 10b). According to previous studies, the desorption peaks of $\mathrm{O}_{2}{ }^{*}$ and $\mathrm{O}^{*}$ located at less than $200^{\circ} \mathrm{C}$ and in the range of $200-350^{\circ} \mathrm{C}$, respectively. The $\mathrm{O}_{2}{ }^{*}$ was regarded as the intermediate of ozone decomposition. The desorption temperature of the peaks attributed to $\mathrm{O}_{2}{ }^{*}$ followed the order: $\mathrm{MnO}_{2}-\mathrm{H}-200-0.2>\mathrm{MnO}_{2}$ H-200-0.6 $>\mathrm{MnO}_{2}-\mathrm{H}-200$, suggesting that $\mathrm{O}_{2}{ }^{*}$ species were relatively stable on the spent catalysts. As the desorption of $\mathrm{O}_{2}{ }^{*}$ is the rate-limiting step for ozone decomposition, the difficult desorption of $\mathrm{O}_{2}{ }^{*}$ on the catalyst hindered the recovery of the oxygen vacancies. As a result, it caused a decrease of active sites and a low ozone conversion. The results indicated though the $\mathrm{O}_{2}{ }^{*}$ desorption process was relatively reversible for $\mathrm{MnO}_{2}-\mathrm{H}-200$, the residual $\mathrm{O}_{2}{ }^{*}$ difficult to desorb from the surface of the catalyst might hinder the subsequent cycles, hence decreasing its active sites with time. 

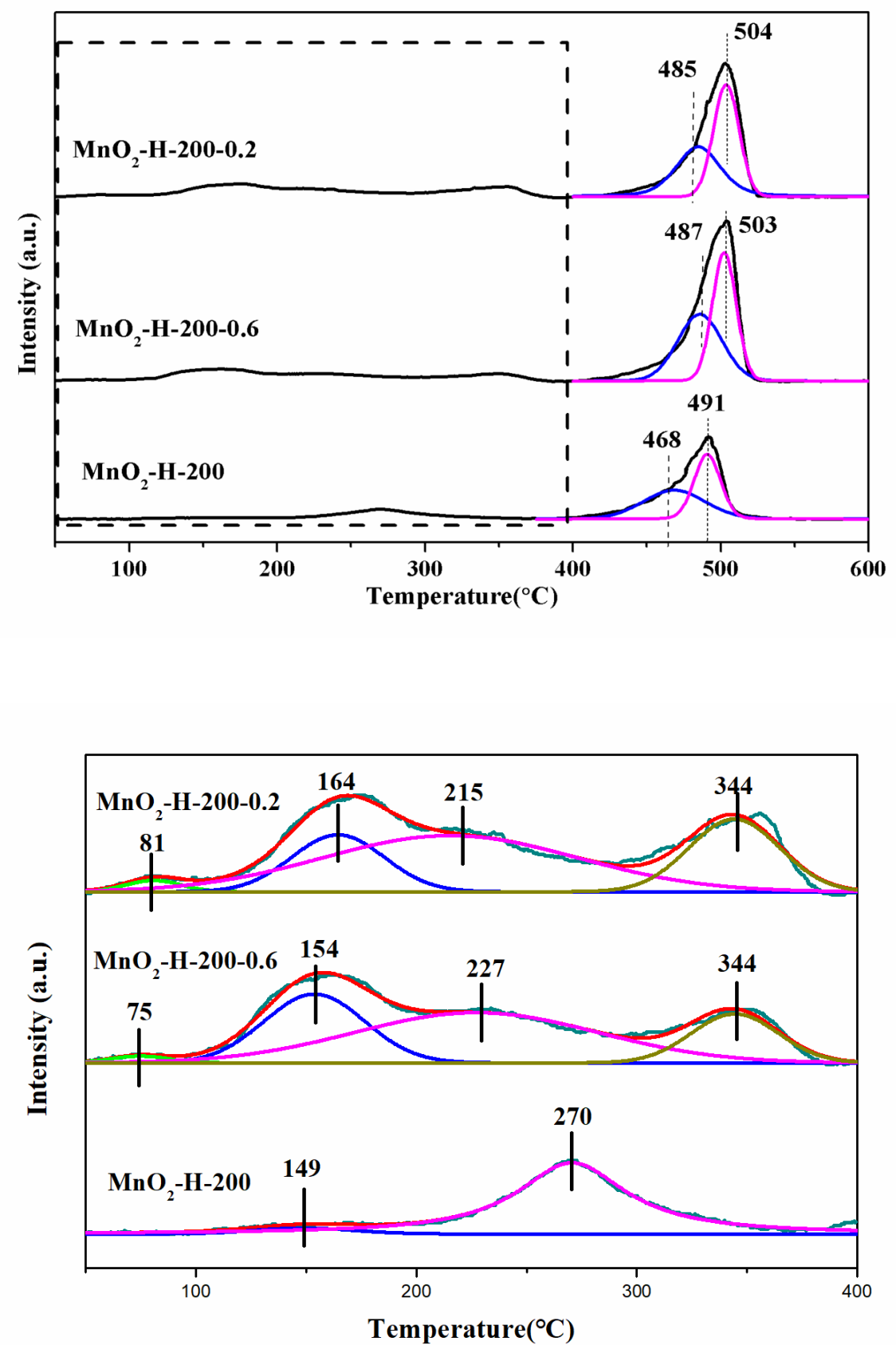

Figure $10 . \mathrm{O}_{2}$-TPD profile of $\mathrm{MnO}_{2}-\mathrm{H}-200$ at different ozone conversion (1, 0.6 and 0.2 ): (a) the temperature range of $50-600^{\circ} \mathrm{C}$ and (b) the peak-peak fitting at the temperature range of $50-400^{\circ} \mathrm{C}$

For $\mathrm{MnO}_{2}-\mathrm{H}-200$, two desorption peaks occurring at $468^{\circ} \mathrm{C}$ and $491^{\circ} \mathrm{C}$ were attributed to the gradual escapes of the lattice oxygen close to the surface and the bulk oxygen species, respectively. They both shifted to higher temperature for the spent catalysts, which indicated that oxygen mobility got weakened and the strong $\mathrm{Mn}-\mathrm{O}$ bond was formed in the octahedral $\mathrm{MnO}_{6}$ framework. The consistent results were obtained in $\mathrm{H}_{2}$-TPR (Figure 11). Generally, when oxygen vacancies were introduced to $\mathrm{MnO}_{2}$, the formation of $\mathrm{Mn}^{3+}$ could result in the Jahn-Teller distortion and thus facilitate to weaken Mn-O bond. So the lower oxygen mobility of the used catalysts might be caused by the unrecovered oxygen vacancies. 


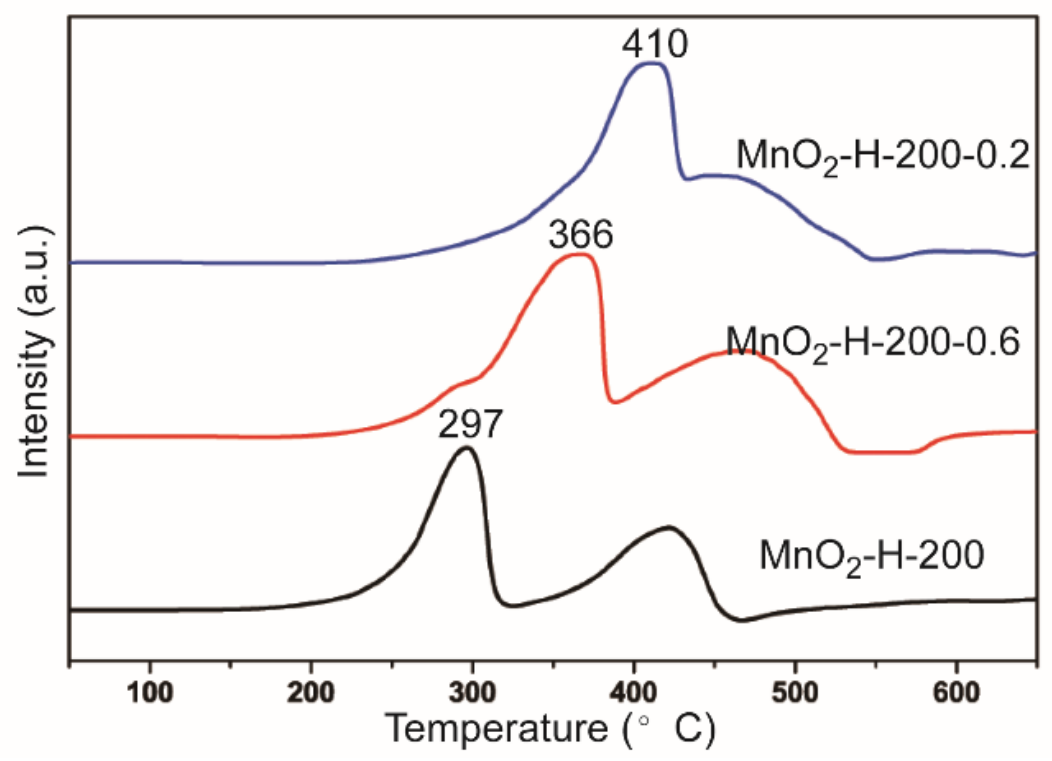

Figure $11 . \mathrm{H}_{2}$-TPR profile of $\mathrm{MnO}_{2}-\mathrm{H}-200$ at different ozone conversion (1, 0.6 and 0.2$)$

In order to further confirm the influence of the accumulation of $\mathrm{O}_{2}{ }^{*}$ on the catalysts, the structures of $\mathrm{MnO}_{2}-$ H-200 before and after reaction were analyzed by XRD as shown in Figure 12. The diffraction peaks of the reacted catalysts corresponded well to the standard PDF card (JCPDS 72-1984) of $\mathrm{MnO}_{2}$ and no extra impurities were observed, which indicated that the accumulation of $\mathrm{O}_{2}{ }^{*}$ had slight effect on the catalyst crystal structure or the changes were too trivial to detect.

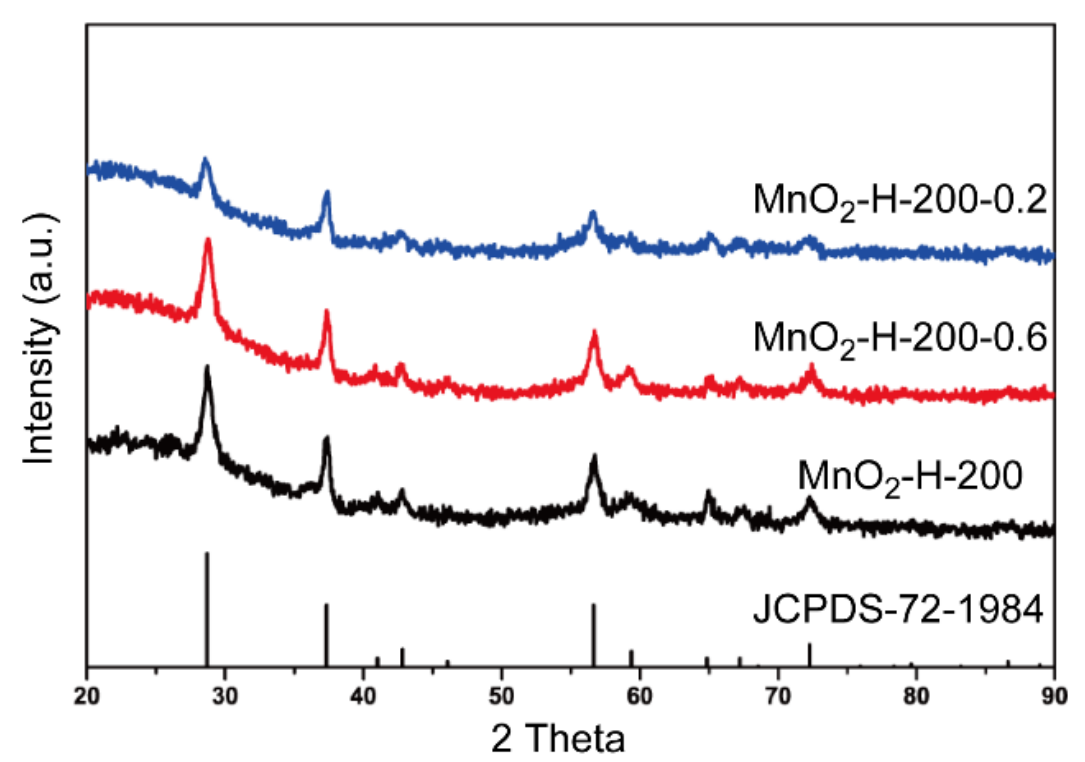

Figure 12. XRD patterns of $\mathrm{MnO}_{2}-\mathrm{H}-200$ at different ozone conversion (1, 0.6 and 0.2$)$

Further evidence on the micro-structural transformation during deactivation was obtained by Raman spectra 
(Figure 13), which can afford abundant information on short-range structure. For $\mathrm{MnO}_{2}-\mathrm{H}-200$, its characteristic peaks were centered at 533 and $665 \mathrm{~cm}^{-1}$, which were attributed to the stretching mode of the Mn-O bond in $\mathrm{MnO}_{6}$ octahedra in $\beta-\mathrm{MnO}_{2}$. While a new peak at $574 \mathrm{~cm}^{-1}$ appeared on the spectra of the reacted catalysts, which was indicative of the stretching vibrations of $\mathrm{MnO}_{6}$ octahedra with an interstitial space consisting of $(1 \times 2)$ channels [37-40]. It reflected a formation of $\gamma-\mathrm{MnO}_{2}$ structure for the reacted catalysts, suggesting that the adsorbed intermediate oxygen species transformed into lattice oxygen. It was further elucidated that the irreversible desorption on $\mathrm{MnO}_{2}-\mathrm{H}-200$ led to the loss of active sites and a decay of ozone conversion.

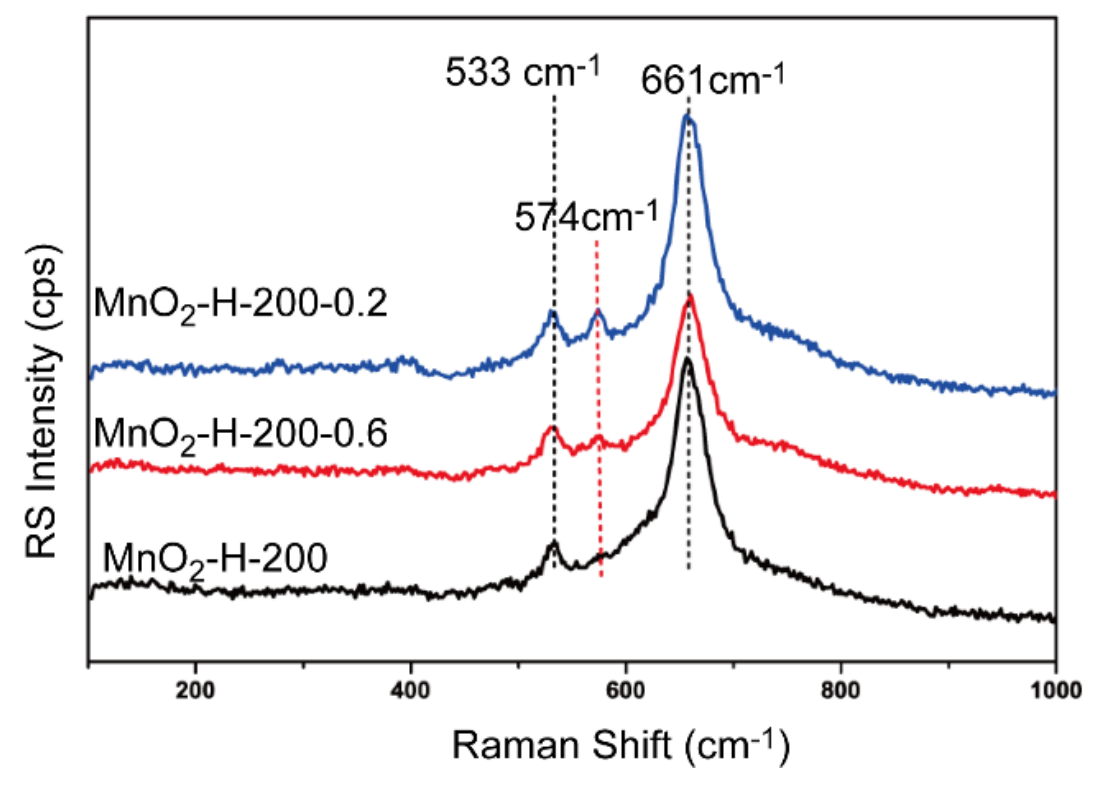

Figure 13 . Raman spectra of $\mathrm{MnO}_{2}-\mathrm{H}-200$ at different ozone conversion (1, 0.6 and 0.2$)$

\section{Conclusions}

A series of $\mathrm{MnO}_{\mathrm{x}}$ catalysts $\left(\mathrm{MnO}_{2}, \mathrm{Mn}_{2} \mathrm{O}_{3}\right.$ and $\left.\mathrm{Mn}_{3} \mathrm{O}_{4}\right)$ with different $\mathrm{Mn}$ valences were synthesized by calcining $\gamma-\mathrm{MnOOH}$ through tuning the calcination temperature and atmosphere. $\mathrm{MnO}_{2}-\mathrm{H}-200$ was obtained by reducing $\mathrm{MnO}_{2}$ using hydrogen. The catalytic activity of the above $\mathrm{MnO}_{\mathrm{x}}$ towards ozone decomposition followed the order of $\mathrm{MnO}_{2}-\mathrm{H}-200>\mathrm{MnO}_{2}>\mathrm{Mn}_{2} \mathrm{O}_{3}>\mathrm{Mn}_{3} \mathrm{O}_{4} \cdot \mathrm{MnO}_{2}$ showed better activity than $\mathrm{Mn}_{2} \mathrm{O}_{3}$ and $\mathrm{Mn}_{3} \mathrm{O}_{4}$ due to its lower formation energy of oxygen vacancy and desorption energy of peroxide species. Especially among three catalysts, the least desorption energy of peroxide species on $\mathrm{MnO}_{2}$ facilitated to the occurrence of rate-limiting reaction step. The surface oxygen vacancy got enriched for $\mathrm{MnO}_{2}-\mathrm{H}-200$ by $\mathrm{H}_{2}$-reduction. The results elucidated that both the nature and abundance of oxygen vacancies have a decisive influence on the catalytic decomposition of ozone. Take an example of $\mathrm{MnO}_{2}-\mathrm{H}-200$, the insights on deactivation mechanism further validated that the catalytic stability of $\mathrm{O}_{3}$ decomposition was strongly associated with the regeneration capacity of oxygen vacancy. The transformation from adsorbed oxygen species to lattice oxygen led to an irreversible generation of oxygen vacancy, which changed the property of the surface of the catalysts and resulted in the difficult desorption of $\mathrm{O}_{2}{ }^{*}$. Hence it caused the deactivation of the catalyst.

\section{Declaration of Competing Interest}

The authors declare no competing financial interest.

\section{Acknowledgements}


This work was funded by the National Natural Science Foundation of China(21676267), the National Key Scientific Research Project(2016YFC0204302), Dalian Institute of Chemical Physics (DICP I201937) and K.C. Wong Education Foundation.

\section{Appendix A. Supplementary data}

The following is Supplementary data to this article:

Catalyst preparation; Catalyst characterization; XRD patterns of the as-prepared $\gamma-\mathrm{MnOOH} ; \mathrm{N}_{2}$ adsorption and desorption isotherms of the different $\mathrm{MnO}_{\mathrm{x}}$ catalysts; Top plane view and the oxygen vacancy sites of the preferentially exposed crystal plane for various MnOx during DFT calculation; FT-IR spectra of $\mathrm{MnO}_{2}-\mathrm{H}-200$ and partially deactivate $\mathrm{MnO}_{2}-\mathrm{H}-200$ catalysts.

\section{References}

[1] R.K. Saari, Y. Mei, E. Monier, F. Garcia-Menendez, Effect of Health-Related Uncertainty and Natural Variability on Health Impacts and Cobenefits of Climate Policy, Environmental science \& technology, 53 (2019) 1098-1108.

[2] Z. Chen, L. Yang, Y. Huang, P. Spencer, W. Zheng, Y. Zhou, S. Jiang, W. Ye, Y. Zheng, W. Qu, Carcinogenic risk of N-Nitrosamines in Shanghai Drinking Water: Indications for the Use of Ozone Pretreatment, Environmental science \& technology, 53 (2019) 7007-7018.

[3] J.H. Xiao Lu, Lin Zhang,Owen R. Cooper,Martin G. Schultz, Xiaobin Xu,, M.G. Tao Wang, Yuanhong Zhao, and Yuanhang Zhang, Severe Surface Ozone Pollution in China A Global Perspective, Environmental Science \& Technology Letters, 5 (2018) 487-494.

[4] C. Weisel, C.J. Weschler, K. Mohan, J. Vallarino, J.D. Spengler, Ozone and ozone byproducts in the cabins of commercial aircraft, Environmental science \& technology, 47 (2013) 4711-4717.

[5] C.J. Weschler, Ozone in Indoor Environments: Concentration and Chemistry, Indoor Air, (2000) 269-288.

[6] B. Dhandapani, S.T. Oyama, Gas phase ozone decomposition catalysts, Applied Catalysis B: Environmental, 11 (1997) 129-166.

[7] Y. Liu, P. Zhang, J. Zhan, L. Liu, Heat treatment of $\mathrm{MnCO}_{3}$ : An easy way to obtain efficient and stable $\mathrm{MnO}_{2}$ for humid $\mathrm{O}_{3}$ decomposition, Applied Surface Science, 463 (2019) 374-385.

[8] M. Wang, P. Zhang, J. Li, C. Jiang, The effects of Mn loading on the structure and ozone decomposition activity of $\mathrm{MnO}_{\mathrm{x}}$ supported on activated carbon, Chinese Journal of Catalysis, 35 (2014) 335-341.

[9] G. Zhu, J. Zhu, W. Li, W. Yao, R. Zong, Y. Zhu, Q. Zhang, Tuning the K(+) Concentration in the Tunnels of alpha- $\mathrm{MnO}_{2}$ To Increase the Content of Oxygen Vacancy for Ozone Elimination, Environmental science \& technology, 52 (2018) 8684-8692.

[10] J. Jia, P. Zhang, L. Chen, Catalytic decomposition of gaseous ozone over manganese dioxides with different crystal structures, Applied Catalysis B: Environmental, 189 (2016) 210-218.

[11] Wei Li, G.V.Gibbs, S.T. Oyama, Mechanism of Ozone Decomposition on a Manganese Oxide Catalyst. 1. In Situ Raman Spectroscopy and Ab Initio Molecular Orbital Calculations, Journal of American Chemical Society, 120 (1998) 9041-9046.

[12] Wei Li, G.V.Gibbs, S.T. Oyama, Mechanism of Ozone Decomposition on a Manganese Oxide Catalyst. 2. Steady-State and Transient Kinetic Studies, Journal of American Chemical Society, 120 (1998) 9047-9052.

[13] C. Wang, J. Ma, F. Liu, H. He, R. Zhang, The Effects of $\mathrm{Mn}^{2+}$ Precursors on the Structure and Ozone Decomposition Activity of Cryptomelane-Type Manganese Oxide (OMS-2) Catalysts, The Journal of Physical Chemistry C, 119 (2015) 23119-23126. 
[14] Y. Liu, P. Zhang, Catalytic decomposition of gaseous ozone over todorokite-type manganese dioxides at room temperature: Effects of cerium modification, Applied Catalysis A: General, 530 (2017) 102-110.

[15] G. Zhu, J. Zhu, W. Jiang, Z. Zhang, J. Wang, Y. Zhu, Q. Zhang, Surface oxygen vacancy induced $\alpha-\mathrm{MnO}_{2}$ nanofiber for highly efficient ozone elimination, Applied Catalysis B: Environmental, 209 (2017) 729-737.

[16] J. Ma, C. Wang, H. He, Transition metal doped cryptomelane-type manganese oxide catalysts for ozone decomposition, Applied Catalysis B: Environmental, 201 (2017) 503-510.

[17] W. Hong, T. Zhu, Y. Sun, H. Wang, X. Li, F. Shen, Enhancing Oxygen Vacancies by Introducing Na(+) into OMS-2 Tunnels To Promote Catalytic Ozone Decomposition, Environmental science \& technology, 53 (2019) 13332-13343.

[18] S. Gong, W. Li, Z. Xie, X. Ma, H. Liu, N. Han, Y. Chen, Low temperature decomposition of ozone by facilely synthesized cuprous oxide catalyst, New J. Chem., 41 (2017) 4828-4834.

[19] J. Jia, C. Qian, Y. Dong, Y.F. Li, H. Wang, M. Ghoussoub, K.T. Butler, A. Walsh, G.A. Ozin, Heterogeneous catalytic hydrogenation of $\mathrm{CO}_{2}$ by metal oxides: defect engineering - perfecting imperfection, Chemical Society reviews, 46 (2017) 4631-4644.

[20] T. Xiong, Z.G. Yu, H. Wu, Y. Du, Q. Xie, J. Chen, Y.W. Zhang, S.J. Pennycook, W.S.V. Lee, J. Xue, Defect Engineering of Oxygen-Deficient Manganese Oxide to Achieve High-Performing Aqueous Zinc Ion Battery, Advanced Energy Materials, 9 (2019) 1803815.

[21] D.W. Kwon, G.J. Kim, J.M. Won, S.C. Hong, Influence of Mn valence state and characteristic of $\mathrm{TiO}_{2}$ on the performance of Mn-Ti catalysts in ozone decomposition, Environ Technol, 38 (2017) 2785-2792.

[22] E. Rezaei, J. Soltan, N. Chen, Catalytic oxidation of toluene by ozone over alumina supported manganese oxides: Effect of catalyst loading, Applied Catalysis B: Environmental, 136-137 (2013) 239-247.

[23] Ebrahim Rezaei, Jafar Soltan, Ning Chen, J. Lin, Effect of noble metals on activity of MnOx- $\gamma$-alumina catalyst in catalytic ozonation of toluene, Chemical Engineering Journal, 214 (2013) 219-228.

[24] Rakesh Radhakrishnan, S.T. Oyama, Ozone Decomposition over Manganese Oxide Supported on $\mathrm{ZrO}_{2}$ and $\mathrm{TiO}_{2}$ A Kinetic Study Using in Situ Laser Raman Spectroscopy, Journal of Catalysis, 199 (2001) 182-290.

[25] Rakesh Radhakrishnan, S.T. Oyama, Electron Transfer Effects in Ozone Decomposition on Supported Manganese Oxide, Journal of Physical Chemisty.B, 105 (2001) 4245-4253.

[26] J. Jia, P. Zhang, L. Chen, The effect of morphology of $\alpha-\mathrm{MnO}_{2}$ on catalytic decomposition of gaseous ozone, Catal. Sci. Technol., 6 (2016) 5841-5847.

[27] J.D.P. H.J. Monkhorst, Special points for Brillouin-zone integrations, Physical Review B, 13 (1976) 5188-5192.

[28] T. Mishra , P. Mohapatra , K.M. Parida, Synthesis, characterisation and catalytic evaluation of ironmanganese mixed oxide pillared clay for VOC decomposition reaction, Applied Catalysis B: Environmental, 79 (2008) 279-285.

[29] A. Gil , M.A. Vicente, S.A. Korili, Effect of the nature and structure of pillared clays in the catalytic behaviour of supported manganese oxide, Catalysis Today, 112 (2006) 117-120.

[30] J. Chen, X. Chen, X. Chen, W. Xu, Z. Xu, H. Jia, J. Chen, Homogeneous introduction of $\mathrm{CeO}_{\mathrm{y}}$ into $\mathrm{MnO}_{\mathrm{x}}$-based catalyst for oxidation of aromatic VOCs, Applied Catalysis B: Environmental, 224 (2018) $825-835$.

[31] H. Sun, Z. Liu, S. Chen, X. Quan, The role of lattice oxygen on the activity and selectivity of the OMS-2 catalyst for the total oxidation of toluene, Chemical Engineering Journal, 270 (2015) 58-65. 
[32] Y. Yang, J. Huang, S. Wang, S. Deng, B. Wang, G. Yu, Catalytic removal of gaseous unintentional POPs on manganese oxide octahedral molecular sieves, Applied Catalysis B: Environmental, 142-143 (2013) 568-578.

[33] D. Chen, D. He, J. Lu, L. Zhong, F. Liu, J. Liu, J. Yu, G. Wan, S. He, Y. Luo, Investigation of the role of surface lattice oxygen and bulk lattice oxygen migration of cerium-based oxygen carriers: XPS and designed $\mathrm{H}_{2}$-TPR characterization, Applied Catalysis B: Environmental, 218 (2017) 249-259.

[34] J. Hou, L. Liu, Y. Li, M. Mao, H. Lv, X. Zhao, Tuning the $\mathrm{K}^{+}$concentration in the tunnel of OMS-2 nanorods leads to a significant enhancement of the catalytic activity for benzene oxidation, Environmental science \& technology, 47 (2013) 13730-13736.

[35] C.H. Li Yang, Yulun Nie, Jiuhui Qu, Catalytic Ozonation of Selected Pharmaceuticals over Mesoporous Alumina-Supported Manganese Oxide, Environmental science \& technology, 43 (2009) 2525-2529.

[36] J.P.D.A. John M. Roscoe, Diffuse Reflectance FTIR Study of the Interaction of Alumina Surfaces with Ozone and Water Vapor, The Journal of Physical Chemistry A, 109 (2005) 9028-9034.

[37] T. Gao, H. Fjellvag, P. Norby, A comparison study on Raman scattering properties of alpha- and beta- $\mathrm{MnO}_{2}$, Analytica chimica acta, 648 (2009) 235-239.

[38] C. Julien, M. Massot, S. Rangan, M. Lemal, D. Guyomard, Study of structural defects in gama- $\mathrm{MnO}_{2}$ by Raman spectroscopy, Journal of Raman Spectroscopy, 33 (2002) 223-228.

[39] C.M. Julien, M. Massot, C. Poinsignon, Lattice vibrations of manganese oxides, Spectrochimica Acta Part A: Molecular and Biomolecular Spectroscopy, 60 (2004) 689-700.

[40] E. Widjaja, J.T. Sampanthar, The detection of laser-induced structural change of $\mathrm{MnO}_{2}$ using in situ Raman spectroscopy combined with self-modeling curve resolution technique, Analytica chimica acta, 585 (2007) 241-245.

\section{Hosted file}

Figures.docx available at https://authorea.com/users/319462/articles/449195-insights-intothe-roles-of-surface-oxygen-species-of-manganese-oxides-for-the-ozone-elimination-atambient-temperature 